\title{
化學機械に關する特許抄錄
}

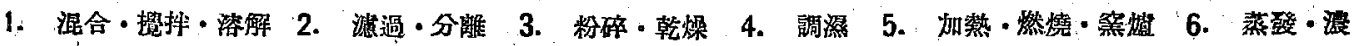

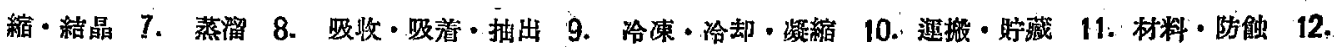

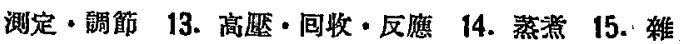
抄錄委員 廣田 徹 - 田邊義一・本閒良之・田燠武夫・濯浦雪男

\section{1. 混合・隐抖・溶解}

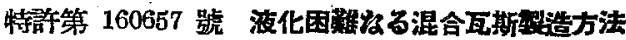

$$
\begin{aligned}
& \text { レール・リキート・ソシエテ・アノニーム・プ } \\
& \text { ール・レチート・エ・レキスプロアタシ*ン・ } \\
& \text { テ・プロセデ・ジョルジュ・クロード }
\end{aligned}
$$

本器明はアンモニア合成用の水素と䇪素との混合ガスヌはメ チールアルコールの様な有機化合物合成用の水素と一酸化炭素 との混合ガスを製造する方法で，湿合ガスを冷却し收得すべ 混合ガスの成分中に加入すべき第一ガスを分離する爫に該冷却 湦合ガスを液化し同樣に收得すべき混合ガスの成分中に加入す へきき第エガスを冷却液化

し，此等の液體狀成分と ガス體狀成分とを泊合 し，該液體狀成分は之を 源加するに當つて少くも 其の一部分が蒸發しない 樣に充分低溫で多量とな し，斯くして得られたガ ス體と液體との湦合物を 冷却すべきガス例へば處 理寸べき混合ガスに其の

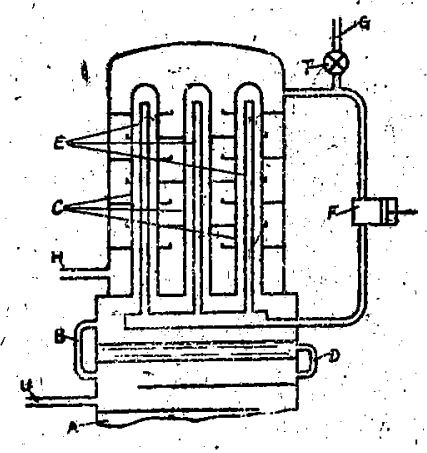

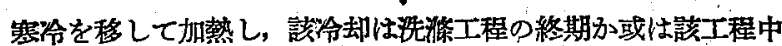

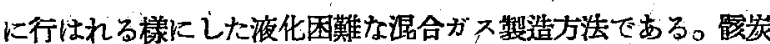
譃ガスより， $\mathrm{N}_{2}+3 \mathrm{H}_{2}$ 組成のガスを製造する場合には，距め冷 却され部分液化に依りエチンンと大部分のメタン及び酸化炭素

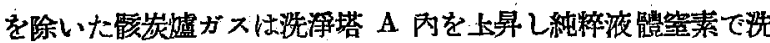
はれ塔頂で得られる純粹な窒素と水素との混合物は管 B を通 り上端開塞せる束管 C k送られ，束管 $\mathrm{C}$ は空素が凝縮する 程度に外部より冷却やられ，此堂素が管 D を通り塔 $\mathrm{A}$ 頂上

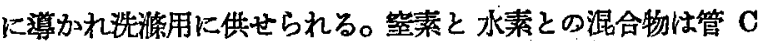
の項上より管 $\mathrm{E}$ を羊つて降り管內 $\mathrm{C}$ を通るがスにより間接加 熱され膨脹機 F にスり外部仕事をしながら膨脹し寒冷を生ず

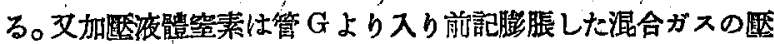

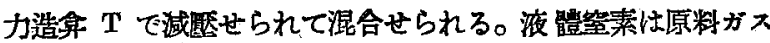
を其の成分に分離して得た生成物之熱交換に依り冷却せられ， 其の量け膨脤した水索と啌素の混合物と結合して生じた泥合物 が全く $\mathrm{N}_{2}+3 \mathrm{H}_{2}$ の組成と成る保度とする。以上の條件で莩入 された液體䆟素とガスとより成る混合物は外管 0 を冷却し自 らは加熱せられて管Hより抽出される。（田邊義一）

$$
\text { 2. 滤過 - 分 離 }
$$

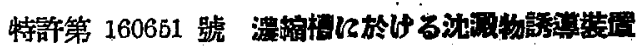

$$
\text { ? }
$$

藤重初治郎

本發明は澧密槽 1 の中心部认筒杜 2 を垂立し, 之に上下雨 端部周圍に數個の洗通孔 $3 ， 4$ を察設し队部に推進营 5 を四 轉し得るゃうにし，數多のレーキ6 6 は連鎖 7 で何轉樘８の

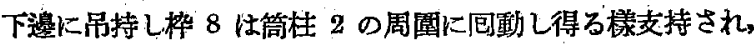
上部の牛徑枠 9 で濃密槽周緣の軌道 10 上を轉々寸る轉輪 11

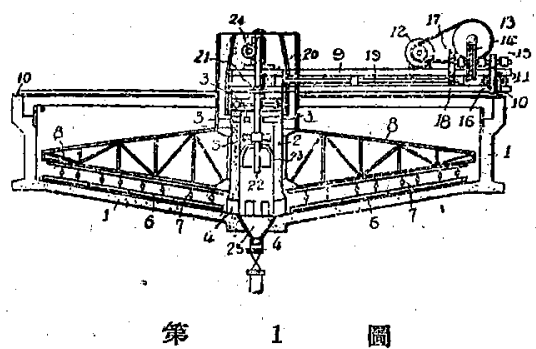

を備へて桦 9 上の電動機 12 により傳動して驅動して柊 8 を 回動し, 電動機 12 の四動機の包動はウェーム 13, 图車 14;15, 16. を介して轉輪 11 に傳動し番車 17，18を介し軸 19 を回轉

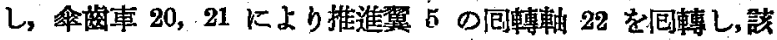
軸 22 は上下動自在とし道道 23 , 苜車 24 により上下動して罴 5 の 位置を調節し流量を任意に加減し 得る樣にしてある。枠 9 は一端部を 柱 2 の上端汇四轉自在に支持し枠 8 を取付け, 凟 问轉軸下端を㜢板 23 飞軸支し，绕 劃板 23 に通孔 24 を閉穿して此の 通孔 24 と推進翼 5 との間隔によ

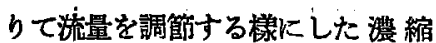
槽に於ける沈没物誘導裝置である。 レーキ6 Kよつて沈激物を中心に 向ひ抒集める作用を助勢し，濃縮槽

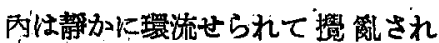

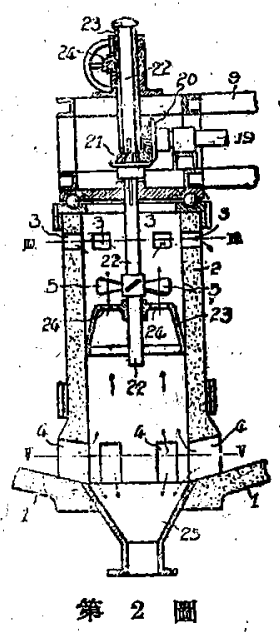
ることがなく，沈洪作用を妨害しないで沈激物を中心に集める ことが出來, 筒杜 2 內の液は押上げられ沈源物を取出口に集め てもロ部に附着停着することがなく，道度の㩭汼作用を與へな

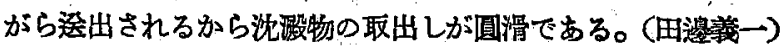
特等第 160724 號 豆局憈過器の慗造法

品川白㗪瓦株式會往

本發明は硬石青ブラスタースは燒石高或は之等の混合物を硬 
化劑とする二種以上の濾過性能 の異なる累質の溜過體配合物を 二層头上數層に累積硬化し之を 㷪成して多層㴗過體を製造する 万法であつて; 珪藻土,シャも， ト，珪砋等の濾過體の主成分を なナ配合物に前記の硬化初を加 一密加する時は成形時に於て自 ら硬化成形する特徽を持つてる る。例一は潜办用除菌濾過 筒の 場合は，細菌の阻留完全な密貿

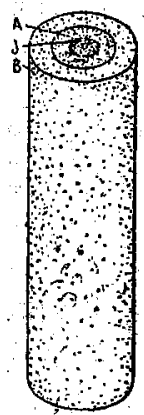

第 1 圖， 滤過體調合物 $\mathbf{A}$ 及㝊び之より粗質で濾過速度の大きい爈過體調 合物 B を用意して最初に滤過筒內側に相當寸る太さに調合物 A で圆筒を成形し硬化した後外側に所要の厚さに調合物 Bを累 䞍成形し, 其の硬化時に $\mathrm{A} ; \mathrm{B}$ は何れも硬化して一體の濾渦筒 を形成し之を爈中に裝入して約 $1,000^{\circ} \mathrm{C}$ k燒成すると $\mathrm{A}_{3} \mathrm{~B}$ は

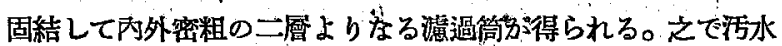
を湆渦すると微細な細菌類を阻留し淨化せられる。Aの材料は

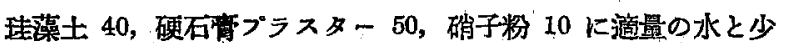

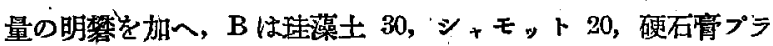
スター 30, 燒石育 20 の割合它使用する。(田邊義一)

特許第 160771 號 遗心分離绕 東生 孝重

從來含液䯣より母夜を脫水分離する㒉心分離穖は通常バスク っトに多数の小孔のある包轉筒を主に使用し不銹鋼で製作し又 は鉆等を被覆してるるが, 母夜が强酸等の場合は陶磁 器等が最もよいが機械的强 度脆弱で大型又心高速回轉 等の場合は不適當である。 本發明は之等の缺點を改良 乙陶磁器の耐玲性を利用し 不銹鍶，鉛等を使はず制作 の容易な工業的使用に耐へ

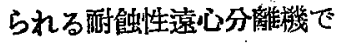
らつて, 內面に母夜排除用 凹瑇 4 を設け大截頭圓踓形 の陶磁器製無孔内筒 3 を機 械的强度の大きい、鐵製補强 外筒 1 :保護し, 兩者の間 に䎄性ゴム接着層 2 を以て 一體化したものでする。 は底部仁傾科してるる凹灌

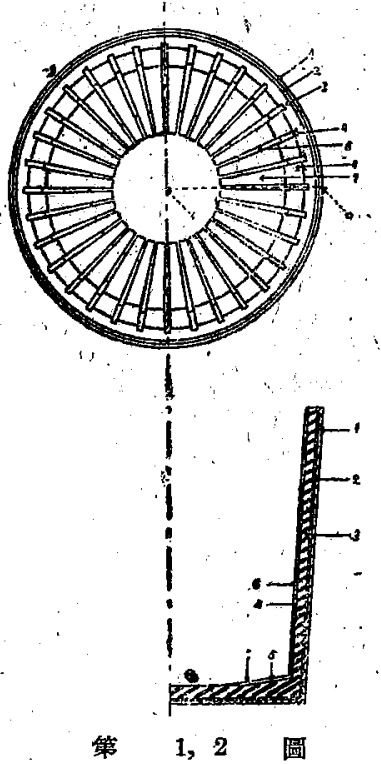

6 友び 7 は凹嗨を形成する篇の凸部で，其の内 面に金網濾布 等を張り付ける。硫酸酸性母夜の附着した結晶硫安を此の機を

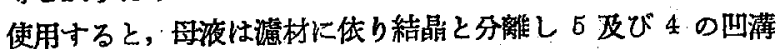
を通つて機外に排除せられ，母夜の分離が終れば結晶を取り出 すのだある。(田勘義一)

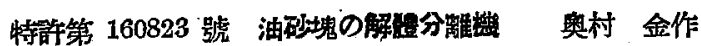
此の發明は石油の涌出不能となつた枯渴油扑の底部より油砂 坮を探つて之より油分を四收する第めの裝置でせつて，先ゔア ルカv性液體を管 12 とて槽 1 内に供給すると共に加熱管 13 に蒸氣を通じて液體を加蓺し文中心軜 4 冈管 5 .及突起 6 を回
轉させた狀態に於て管 2るり油砂塊を投入す る。然る時は油砂塊は 槽 1 の內側に沿つて下 降せんとするも大部 分は前記液體の上昇流 動に妨げられ一旦 圆筒 5. 內降し隔殹 8 上 より外方に折返して㭶 液體の上䒜流動に沿ひ 多數の突起 3 友 6 間に 揉まれつつ上昇して渐 次解體し斯〈て之等の 突起 3，6による解體作 用と加熱液體の洗 源作 (用を受けて油分を離脫 せる砂粒于は通路 7 上 り徐々に下降し排砂口 14 上に集積するのであ る。而して此の 集積粒 子の重量力彈機 17 K

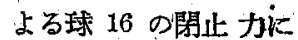
打腪つ程度となれば排 仯口 14 㹥集積粒子の
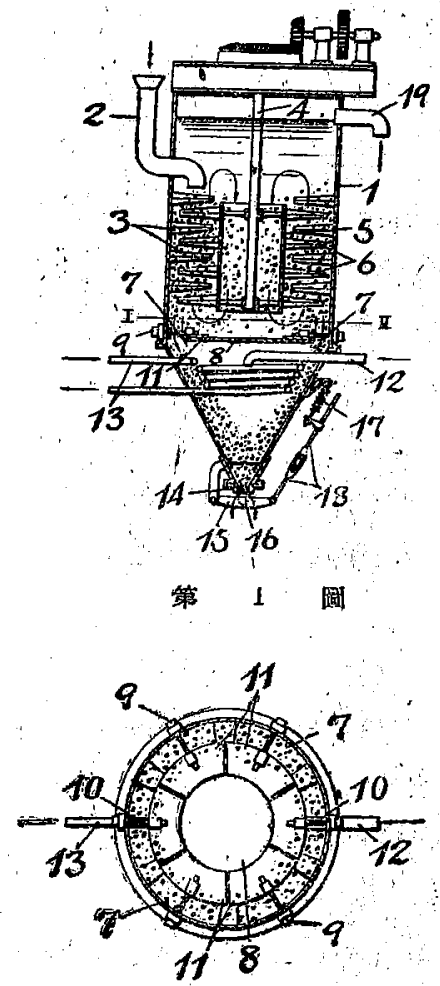

策 2

重量に比例する閉度を保つて排砂粒子の自動的排出を可能とな すのである。尚離脫せる油份は液體と共に溢出管 19 より流出 乙別の昜所に於て比重美等により完全に分離し得られる，のであ る。(澤浦)

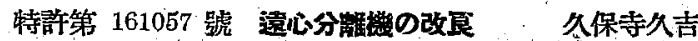
從來回轉槽に分崔せんとする液體を入れて高速包轉与る事に

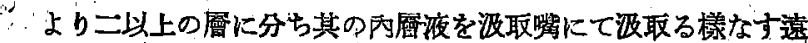

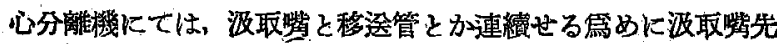

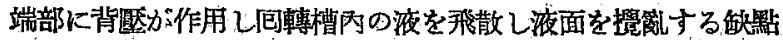
ありたるす，此め發明は之を改善せるすのですつて，服取路 2 を
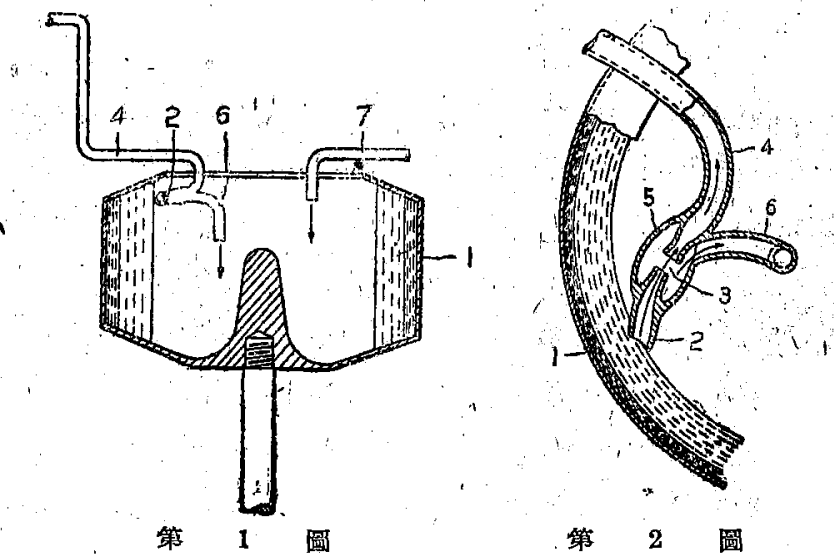

出來るだけ短小となし其の後端に面して小許の間吵 3 を存して 移迨管 4 端を對向せしめ且其の對向部を被䇫 5 にて被覆し，以て

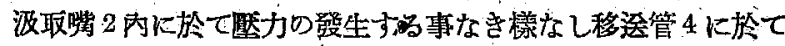

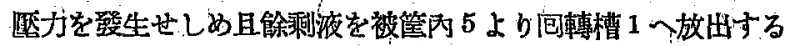

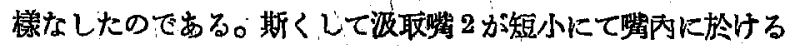




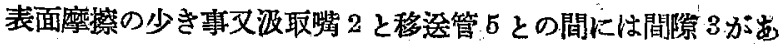

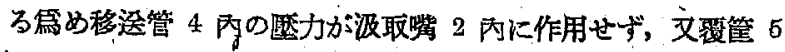

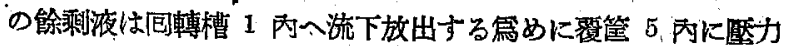
が發生せざる事により泿取嘴 2 內に壓力の發生なく從つて泿

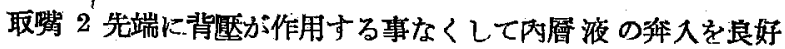
となし得るのである。(澤浦)

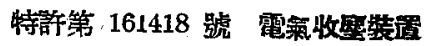

日本劉業株式會社。株式會社日立製作所

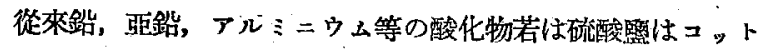
レル式收麾裝置にては夫等の微粒子の附着力强固な爲め䉓極上 の堆観物は其の離脫困難にて特にガスの盜度低い場合は甚しく

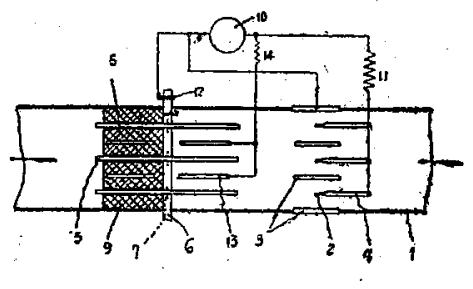

第 1 圆

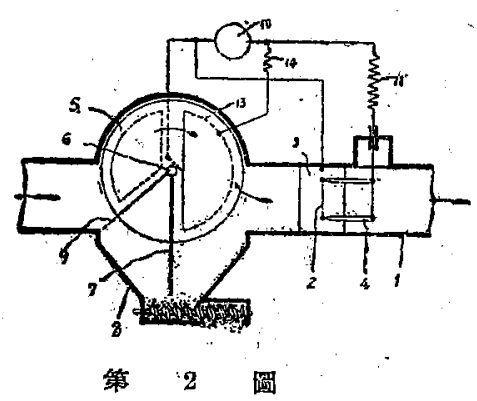

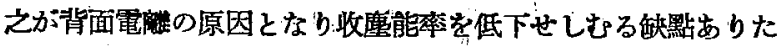
るを，此の發明は之を改良せるものであうて，ガス通路を知印 の如く运られるガスは放電々極及對極 2 及對極 3 間を通過する 間に其の電界により浮游微粒子は徛麗され之が夼分なる展開面 を有する導雷性收摩板 5 に達して電荷を失ひ始に沈積するので

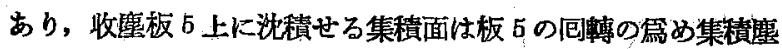

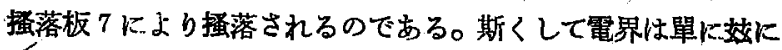
飛來する微粒子に電荷を附與するに止り收蝔作用は主として電 界外に於てガス流に對し充分な展開面を有し且常に可轉拭除せ

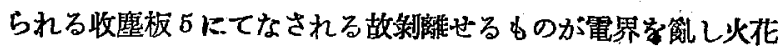

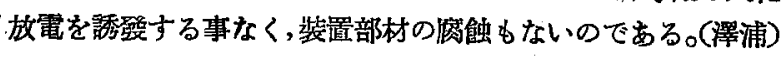

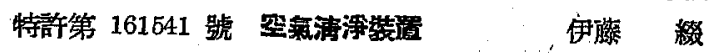

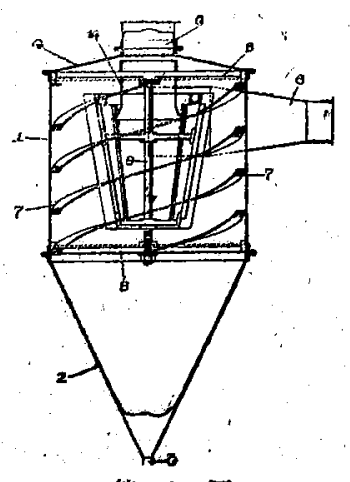

第， 1 圆

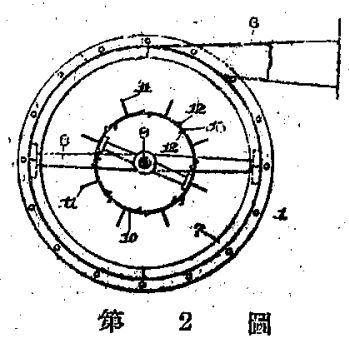

此の登明は主として噴射研磨䅋の使用に伐つて生ずる污風を！

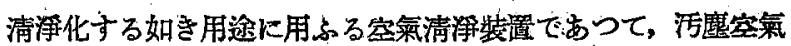
は吹达管 6 上り切線方向仁從つて胴 1 内に流入儿螺挍導版 7 K て逐次螺族に埒加れ旋回せられつつ流下寸方間に空氣中の比重

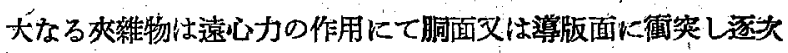
圓錐底2に放出せられるのである。而して篓流は胴の下端によ

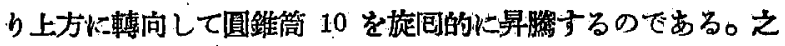

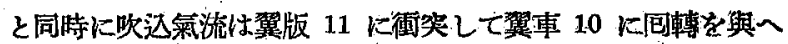

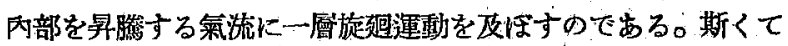

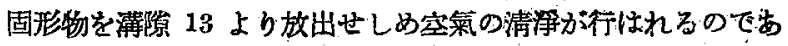
る。(澤浦)

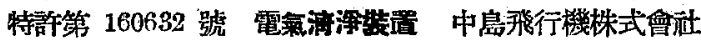

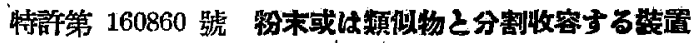

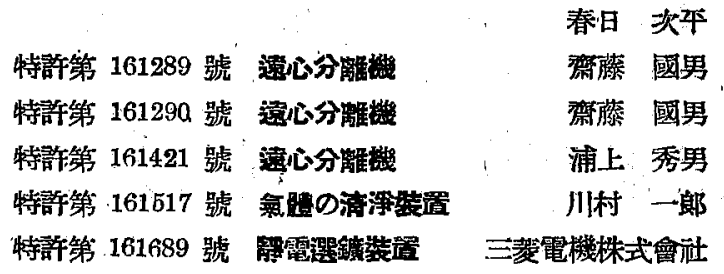

\section{3. 粉 碎}

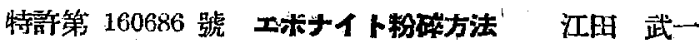

\section{4. 乾 燥・調 濕

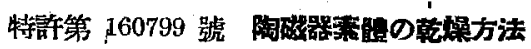

日本䄍子株式會社

本發明は缹潤狀態の陶磁器素體夫れ自身に電流を通して內部 に吸着せる水分の分離發散を助熱し抵抗熱々共働して迅速に且 均樣に陶磁器素體を乾煤する方法であつて, 局部的の急乾を起 寸事がなく全體を略々一樣に且迅速に乾燥する 事が出來るの である。踢面の樣な電氣絕線 碍管 1 を例人ば流し込み法で作 b侣渠潤狀態の物に電極 $A, B$ を附着し導線 2,3によつて適 當の電源例へば普通商用周波數

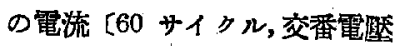
200A，最大 3A]を通ずると素 體 1 は全體として一樣に溫めら れ內部の水分を驅逐して迅速に 乾燥する。例べば乎均直徑約

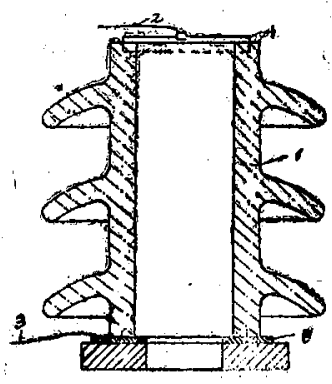
$40 \mathrm{~cm}$, 高さ約 $50 \mathrm{~cm}$, 肉厚 $5 \mathrm{~cm}$ 程度の䅞管素體を從來法の如く乾燥公に入れ外面より坴氣によ つて乾燥すると数遠間を要し外面だけ乾燥し户部に水分为止ま

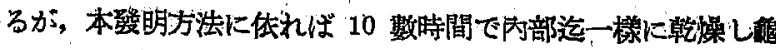

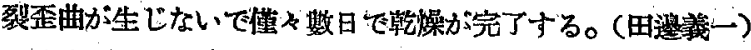

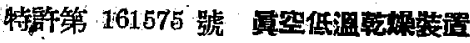

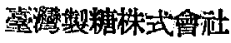

此の發明は生醉母，ビタミン，ホルもン，䤃素等の如き耐熱 性乏しく不安定なる榮美素を破燷せずに連續的に短時間に乾燥 する篇めの裝置であつて，原料處理液を原料補給槽 5 より海綿

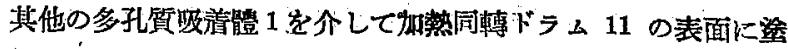

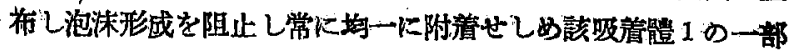


を冷却套 2 にて圍䕒し過剩液 並に同轉ドラム11 の包監 20 に涯下し䝪溜せんとする原料 液は加熱圈外に不斷䀧引䌷出 し共に冷却器 7 を經て冷却 し變質を防止しつつ偱環的に

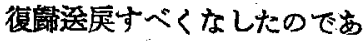
る。而して導管 16 より吸氣

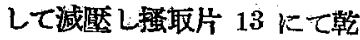
燥物を掻取り受室 14 に落下 せしむるのである。(澤浦)

\section{5. 加熱・燃燒・空爐}

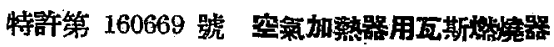

$$
\begin{aligned}
& \text { アスカニア, ウェルケ, アグチェ } \\
& \text { ンゲゼルシャフト }
\end{aligned}
$$

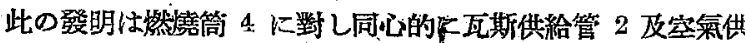
給管 5 を分離して設け，ガスは通路を通りて燃暬筒 4に太り

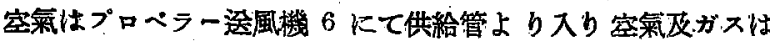
燃猿筒 4 に入る際始めて混合寸る樣なし，之の雨供 給管を有 する管には管內に捚大せられて熱空氣調整に際して聜氣加熱器

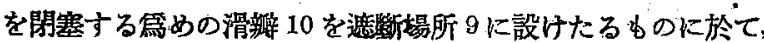

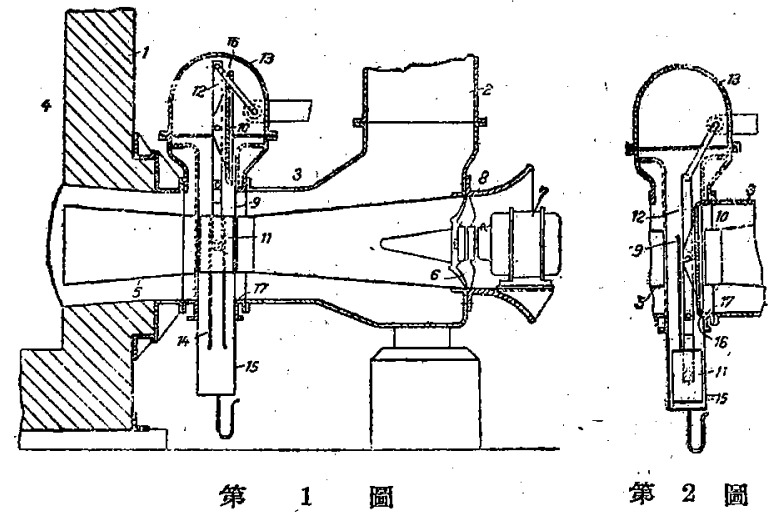

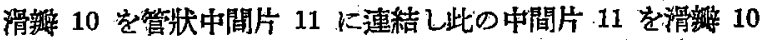
の開放に際し强制的に供給管 2 內に入らしめて ガス と空氣と

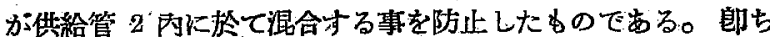

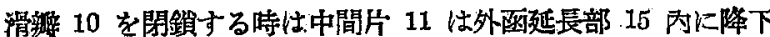
乙買㩐面 16 が外側管 2 . の相應面 17 に接觸し室氣加熱器を外 部に對し閶鋇するのであり，斯くして然等器の作動に際し管內 に於てガスと空氣が混合するの防止すると共に熱空氣調整に

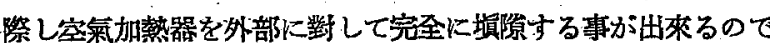
ある。(燡浦)

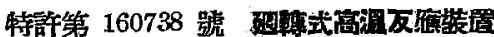

朝山矯治 ・ 岡部光男

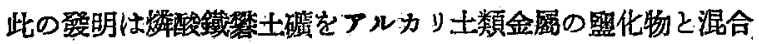

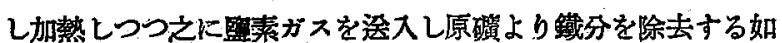
き高溫に於て反應を起さしむる場合に適切な同轉式の反應㧼置 であつて，耐火物にて作りたる切片 1 を數多縱に連結構成せ

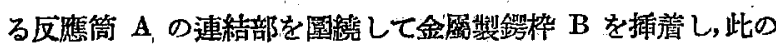
部分にパ,キング 2 を填充して連接部を氣密となし，且前記銍

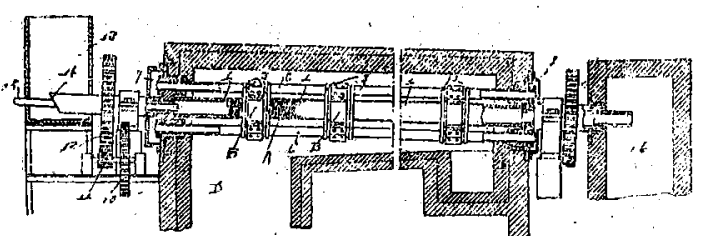

第 $\quad 1$ 圆

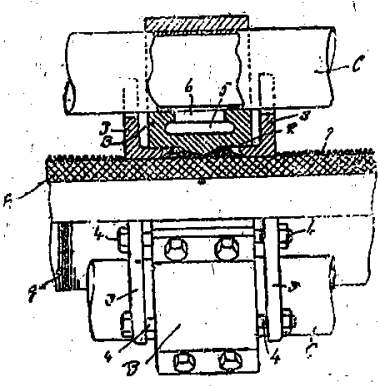

第 2 圆

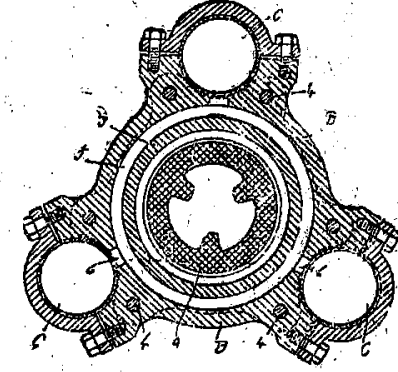

第 3 伃
挆 B には之等を貫通する水管 $\mathrm{C}$ を反應筒 $\mathrm{A}$ と平行に架設し て之を反應筒諸共加熱嘘 D 內にて局動さしむる榚構成なした

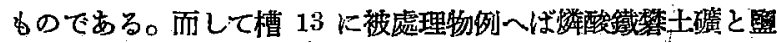
化石灰を共に裝入し爐内を $800^{\circ} \mathrm{C}$ に保ちて反應筒 $\mathrm{A}$ を水管 $\mathrm{C}$ と共に徐々に何轉せしむ。その結果槽內 13 の收容原料は筒

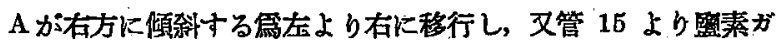
スを吹込む樣なして反應せじむる。

斯くして鍔枠 B は反應筒切片 1 間の佥密連結を强固にし氷 管 C は筒體 A の支へとなり且つ鐸枠 B を冷却して其の加熱 による㦄蝕損傷を少くなし，從つて高熱反應に堪へ永久に有效 に用ひ得る反應裝置が得られるのである。(濢浦)

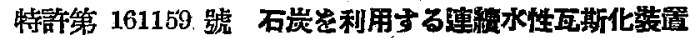

株式會社神户製䤱所

此發明は石炭を利用して水性ガスを連續的に發生するに當つ て，登生爈より生成する乾館ガスの一部分を取出しつつ高溫な る燃酷ガスとの直接接觸により分解せ乙めて所要の水性ガス發 生に充分な熱量及水蒸氣を保有したる睢發生譃內に供給する㦈 なしたものであつて，發生爐 1 に於ける水性ガス化用高溫が ス吹込口 8 に燃垤 9 を設け，該然燒室 9 には精製がスの一

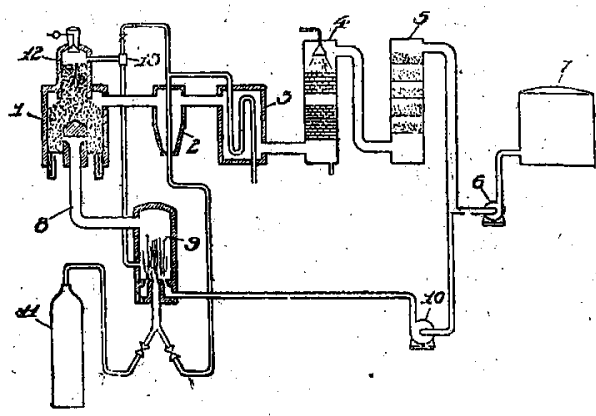

部分を远風機にて供給しつつ之を蒸汽發生器 3 よりの水蒸军と 共に導入せられる酸素供給源 11 よりの酸素々の接觸に依り燃

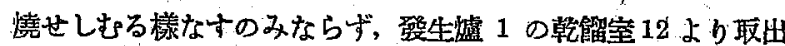
した生成乾餚ガスの一部分を゙蒸汽發生器3よりの水蒸氣の一部 分に上り櫴跴 13 を以て吹込む樣なすので方る。 


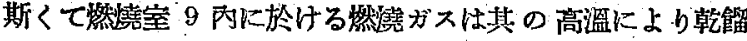
生成ガス中の炭化水素を分解すると共に水性ガス化汹必要な反

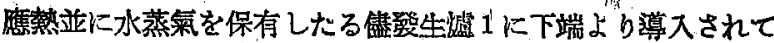

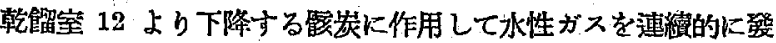
生し得るのである。(濢浦)

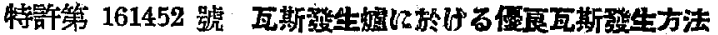
綿弘，正男

此の發明は石炭，木炭文はューライトを燃料とする瓦斯發生 爐に於て，發生嘘內に發生すへきガスの成分を交互に二種類に 變化せしめ其の本均發熱量を犬ならしむる方法であつて，管 3 を蒸氣管に速通し管4より空氣を吸引やしめ管らをガス發生嘘 に連通せしめ斯くてカム 6 を小型電動機にて问轉しか ム 6 の形狀を室氣畣 1 が全 開の時蒸氣弇 2 は奎閶 なり，及反對に蒸氣命 $2 か ゙$ 全開の時空氣斑 1 が全閉と なる樣に与るのである。而 して宾氣弇 1 之蒸氣拿 2 との全開波全閉を交互反對 となし蒸氣の供給の最大量 より漸炏娍少寸るに從ひ空 氣の供給を徐々に增乙最後 に空氣の量が最大となる時 分に蒸氣の供給を絕つ樣稆

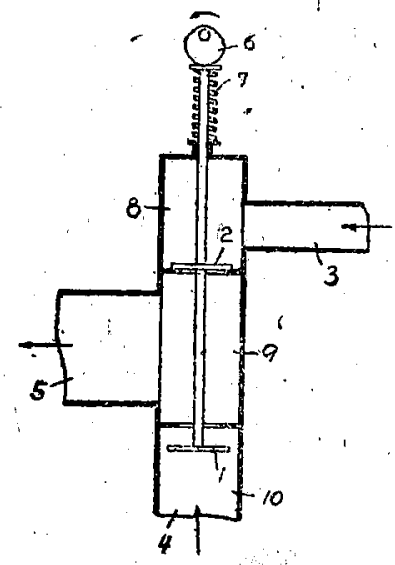

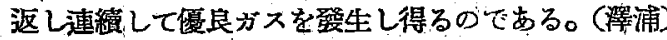

特許第 161470 號 メタン分解用双聯堅姆

$$
\begin{aligned}
& \text { ゲゼルシャフト，コュール，リンデス・ア } \\
& \text { イスマシーネン，マクチェン，ゲゼルシ } \\
& +>ト
\end{aligned}
$$

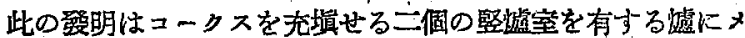
タン含有ガスを交互に通じ酸素を吹込みて燃燋せしめ゙タンを 酸化炭素及水素に分 解せしむるための爈 であつて, 㹂嘘空 1 技 2 にコークス を充填し之に交互に 临入せられるォダン 含有ガスの䝪溫倉の 用をなさしめ，兩㷾 等 1 及 2 以楻通路 3 にて連結しコーク 又灰は流出口4 支 上り排出せしむるの である。而して本發 明にては㹂爐室 1及 2 は下部に於て大體 桻圆形の横断面とな る樣㷋め, 㹂嘘堂 1 は嘴圓形斷面の最大 直俓を横通路 3 の中 心の方向に向はしめ

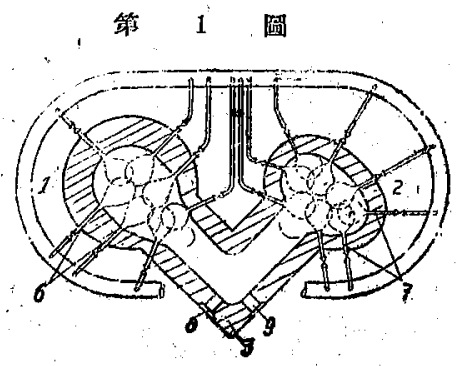

第 2 2 陵
又堅爐室 2は該中心線に直角の方向に间はしむるのである。酸 素はノッズル6 歹 7 より供給せられ，主として檳通路3の中 段平面の高さ认位し各個の酸素ノ、ズルを基點とする燃焅區域

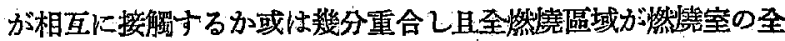

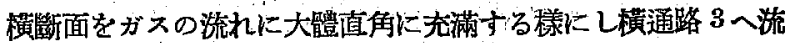
れるメタン合有ガスが其の然燒區域を通過して流れる樣にな すのである。斯くしてュークスを燃埕室へ均一に降下する樣な し，而して作業中に充坥コータスがガス流に對し抵抗を來す事 を防ぎカスの生成能力の低下を防止し得るのである。(浮哺)

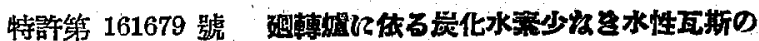
张方法 岩田交治郎

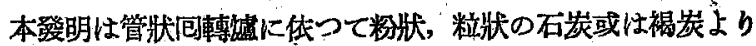
湩續的に水性ガスを發生せしむる方法であつて，问轉㠠の有利 な特性を利用して原糊名炭より数率よく炭化水素の少ない水素 に富さ水性ガスを筡造することが出來る。问轉虚 (1-2-3)は板 金紫の䏤體に耐火䗲瓦の內張を施し少し傾科して轉子に依りタ イャー20を支承し大离車19を駩動して回轉する。此の爈け乾 䬰部 1 ，ガス化部 2 , 灰冷却部 3 より成り兩端火集摩室 4 , 灰 溜空 5 が設けられ，ガス化部 2 恃特に中央部分を膨大にしてあ

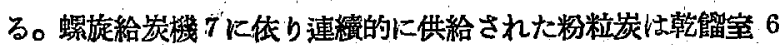

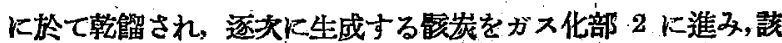
部の下方より方ス化劑と共に前記乾餾に依り生じたガスを吹达

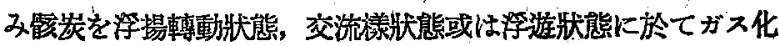
すると同時に該乾餾ガスを䓡分解して水性ガスを生成し，其の

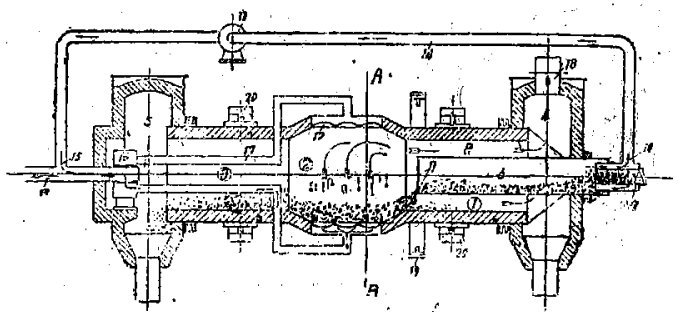

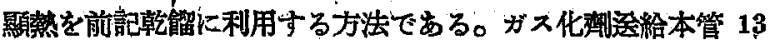
より來るガス化齊たる水蒸氣々酸素或は酸素を加へた空氣との

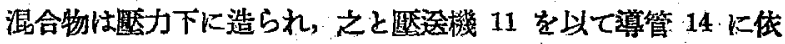
り乾䬰堂6より引き出した䩚餾がスを開口 15 に於て混合し分

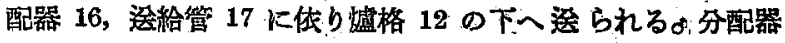
16 は湀給管 17 が 丁 度下方に來たる際に混合ガスを学く榚 な仕組になつてるる。(田息载一)

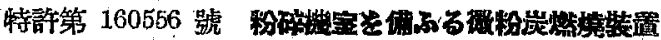

汽車製造株式曾社

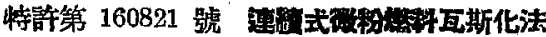

肉宙正规郎

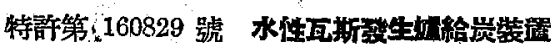

昭和電工株式會邧

特許第 161286 號 木村宸方法 ：岩本 嘉本

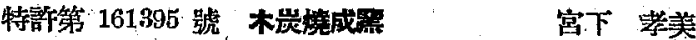

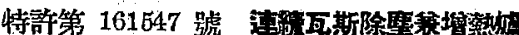




\section{6. 蒸登・謴䑿・結晶}

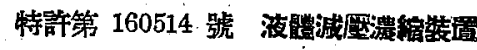
本登明は泡轉機構を有する圆筒形，圆錐形又は英狀の蒸發胴 2 の内壁面に電熱線 4 を裝備して加熱板 6 を張設しこの加熱面 に被浱縮夜学放出さ せるやうに液體吐出 管 47 㗬登胴 2 内 に直立させたもので

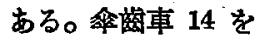
问轉させて蒸登胴 2 を四轉せしめ胴 2 内 を娍壓とし放出口16 から液體を放出せし めると液は加熱板 6 に當り遠心力厄゙加熱 接触面積を增大しつ

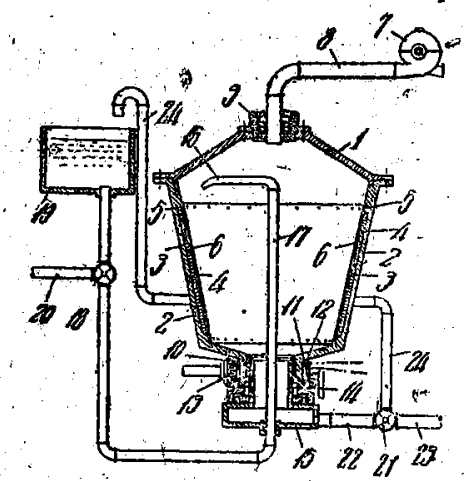
つ受槽 15 亿落下し

管 23 加ら探取される。斯くの如く液體の加熱面に滞溜与る時

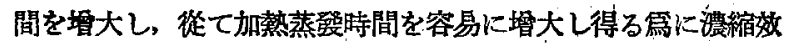
率大である。(田邊武夫)

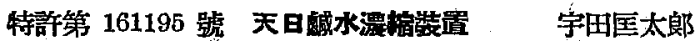

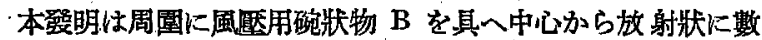

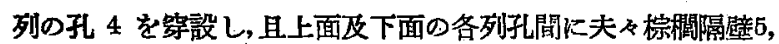
6 を植設した風力回轉四盤 $\mathrm{A}$ を数段に中央管 1 飞他轉自在 に支持し，而してての風力 问轉且盤 A は反對に问轉 する如く碗狀物を取り附け 中央管 1 の頂部の迷出口 9 から此水を进出せしめた 後之を風力で自動回轉する 皿盤上に落下せしめる。落 下践水は四盤上下て動摇さ

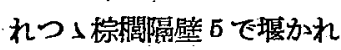
徐々に列孔 4 加ら下方流 出寸るが，其の列孔 4 の下 底部任棕相隔壁 6 が放射 狀酒列してある篇第2段

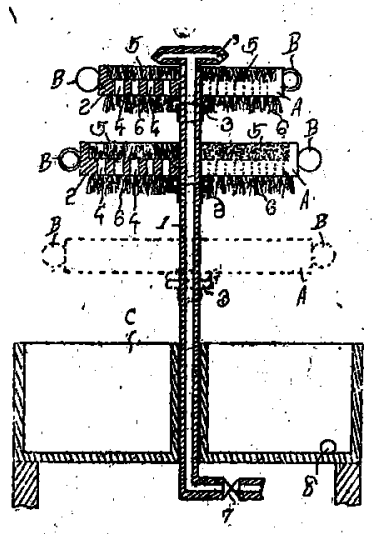
の皿盤 A に落下せしめられ逆に趿握され逐次落下寸る間に濃 樎される。(田邀武夫)

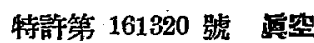

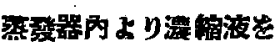
軏的的に抽出する方法 ヨサメ化學機珹 株式會社

本酸明は比較的低位置に 据付けられた蒸墢器 1 (蒸 墢器內の液面办的絊縮槽迄 の高さ注港縮液が自然流下 出來る大氣脚以下例一ば地

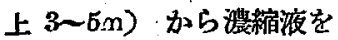

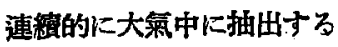

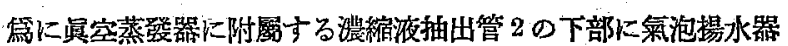
3 を設け, この器底から水蒸氣を吹込々潫縮夜をして蒸氣套 6 で加熱せる上昇管 5 内を上景せしめ高所にある氣液分離器 7 一揚夜寸るめのである。欦込子蒸氣は氣液分離器 7 で分離し蒸

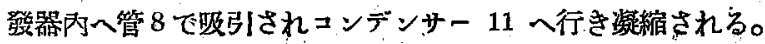
斯くして本發明は抽出ポンプ，又はトラ。プを姴せず簡單飞抽 液することが出來る。（田邀武夫）

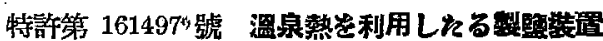
森田 缺治

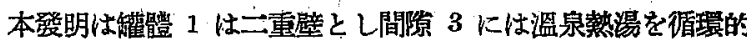

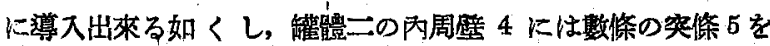

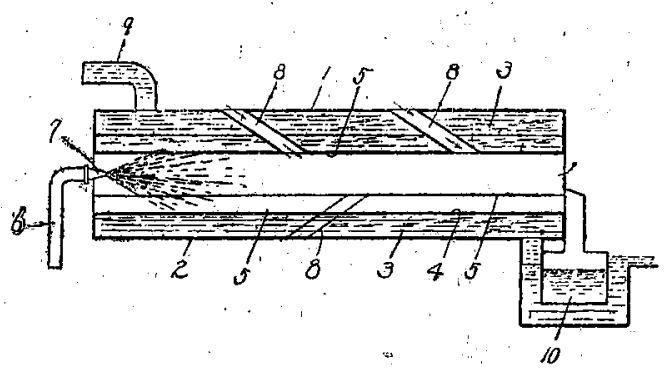

第 1 涸

膨出形成せしめ且維胴の斯個所に は胴壁を貫通して內外端を維體の 內外壁比開口せしめ大吸策管 8 を 噴射方向に射設せしめ，蠸體の一 側開口部々は供給管 6 の一端を軸 心向つて位置せしめ蟈水を噴射 せしめる如くしたすのである。供 給管 6 , 憤射管 7 を經て海水文

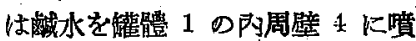
射する時は，海水恃羁となつて中

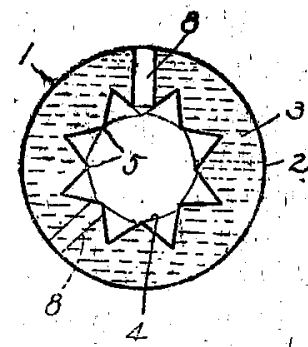

第 2 圆

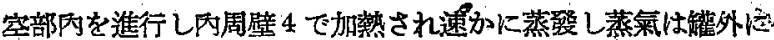

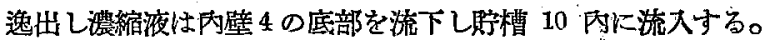
又罐䏸の周壁數個所には噴射方向に向つて給氣管を斜設して西

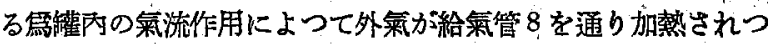
つ襍內中宾部に吸大されるから蒸墢は更に促淮される。 (田邊武夫) ,

\section{7. 蒸 '溜}

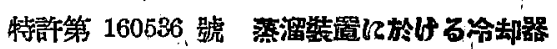

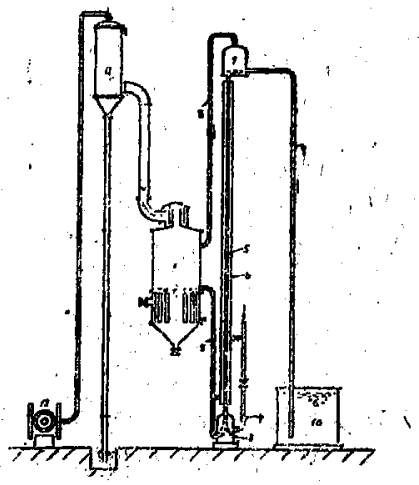

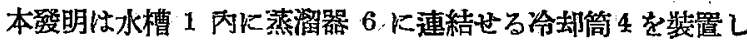

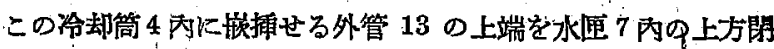
㾞し下方水中で開放し內外の水を連通する如く內匡 10 內の空

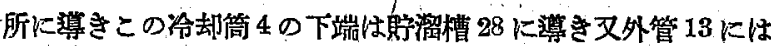

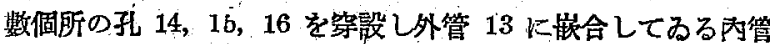
18は內管の摺動で外管 13 の孔の何れか々愺通する孔 $21 ， 22$, 23 を牚ち, 且この內管 18 の內空部恬孔 24 で常に內匣 10 と 連通せしめ, 又的管18は外部加自由操作出來る如く構成し たりのである。蒸溜器 6 から酒精蒸氣を运る時は溜出管らから

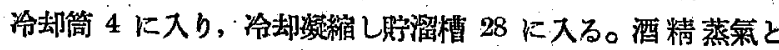
“共に流れてきたアルデヒドは酒精に比し凝維が退いから椧却简 
4 內で凝雓せず孔 14,15 , 16 の何れかから丙管 18 內炕入り更に內匣 10 肉 人上昇士。內邼10 內の 集力增加与る時は肉匣内 の水面(ロ)は下り氣體は 孔11 加水槽內に入り 大氣中认逃出与る。斯く してアルデヒドのみを 氣に放出することが出來 る。(田邀武夫)

特許第 160592 號

醉楼の卧を登溜前に 豦理する裝置

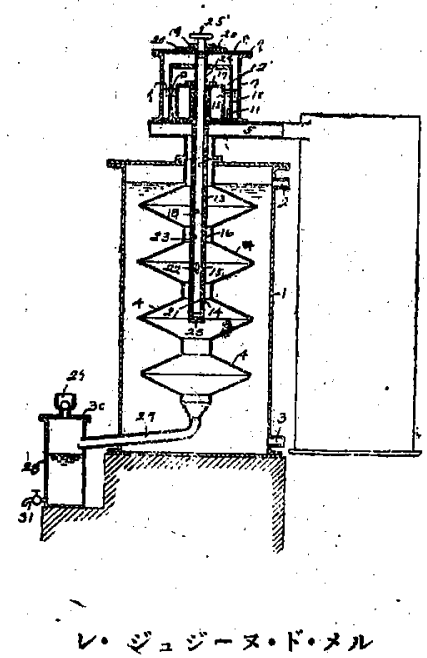

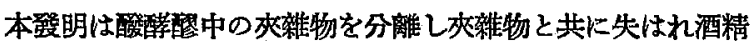
類を完全に採集し且夾雜物を無酸性とし營恙價あるむのとする

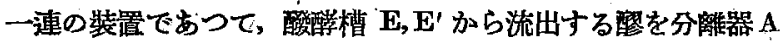
に導き夾雜物を分離した液は管 2 から蒸溜裝置 F に洎き，分離

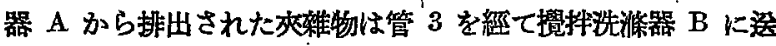
り酒精類,有機酸等を抽出し之を管 4 て次の分離器 $\mathrm{A}^{\prime}$ 江薄き

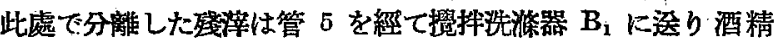
類及酸を抽出せしめ, 之を管 6 で分離器 $A_{2}$ に尊く。更に此

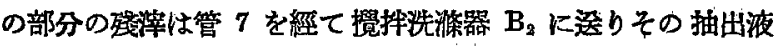

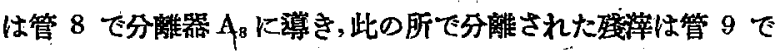
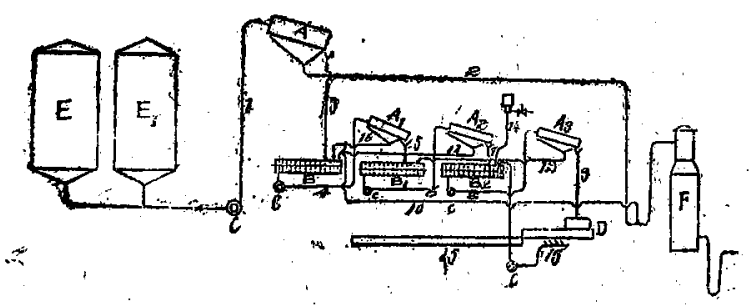

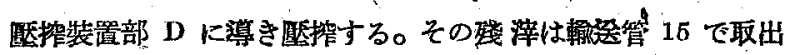
す。各分離器加ら取出される液は其のまま蒸留裝置に導入して

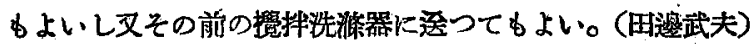

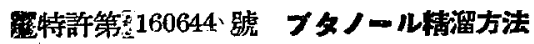

株式會祉明德通商振與會
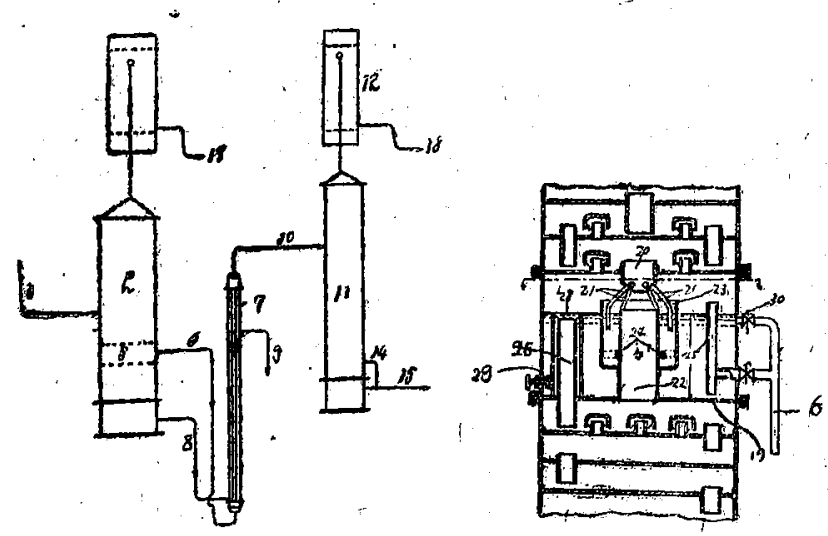

第 1 阅

第 22 四
本發明性酸塔から溜出し。て來た低沸點不純物及水等を含有す る粗プタノールを蒸漼棚板間に高浔分別器 5 を有する精溜荅 2 に導管 1 を䋱て導入し，揮發性高き生成物フルデヒド，アセト ン, エチルナルコール等は塔頂の㠜縮器に流入レ,・ブターール と水との共濟混合物は高溫分別器 5 でブタノールを主とする 層及水を主とする層に分別し水分層は塔を下降しブタノール㕌 は管6で塔外に抽出し数個の小管からなる乳化器7の底部に尊 入する。一方塔底から排出される水を管 8 で乳化器 7 に运り 加熱用に供す。其の時梳小管內のブタノール液は微細なる蒸氣 泡を生じ抙化し管を上景し管 10 を經て自堛的にブタノール脱 水荅 11 に运られる。精溜塔內の高溫分別器

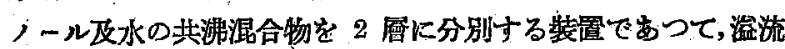
筒 20 ，流下管 21 ，導管 24 を經〔共沸混合物を分離棚 19 上

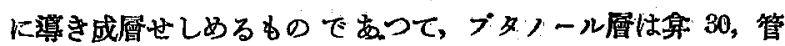
6 を經て塔外几抽出され，水層は畣 29 を經て温流外筒 28 队 へスり更に溢流內筒 26 から下方の棚に远られ更に蒸橴される のである。本發明は高溫分別器及乳化器を設け熱の利用を吅に 為した所に工業的價值大なるものがある。(田邊武夫)

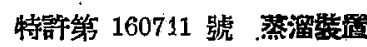

渡息䀡四郎

本登明は初溜塔 1 及原液粗溜塔2よりなる原液粗溜裝置に於 て別に補助荅 4 を獨立して設け，初溜荅１の底部から流出する 原液の一部を管 9 で補助塔4:導入するか及は原液の一部を直 接補助荅 4 に加給寸る如くし, 補助塔 熱管を設け塔 4 肉の原液を加熱する如くし，補助塔 4 の頂部に は溜出蒸氣管 10 を設け，之を初溜塔 1 の底部に連通し補助塔4 の頂部加ら來る蒸氣を利用して初溜塔 1 を加熱せしめる如く したものである。管 6 に 6 \%の酒精を含有する $80^{\circ} \mathrm{C}$ の 酸

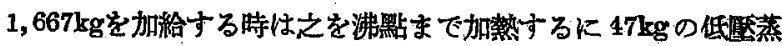

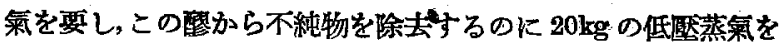
要する䴇結局初溜塔 1 では $67 \mathrm{~kg}$ の水蒸氣肪必要とな る。次に粗溜塔加溜出す る酒精蒸氣は $39 \%$ となる からこの婊度で $100 l$ の酒 精を粗溜塔から溜出させる には $188 \mathrm{~kg}$ の水蒸氣を要 し粗溜裝置全體では $255 \mathrm{~kg}$ となる。然るに $67 \mathrm{~kg}$ の水 蒸氣を敄め補助荅 1 の底部 から加給する時は底部から $450 \mathrm{~kg}$ の水分を排出出來る から管 3を下降与る液は 8 \%以上となり, 粗溜荅 2 か 溜出寸る蒸氣は $46 \%$ 以 上となり, 從つてこの涱度

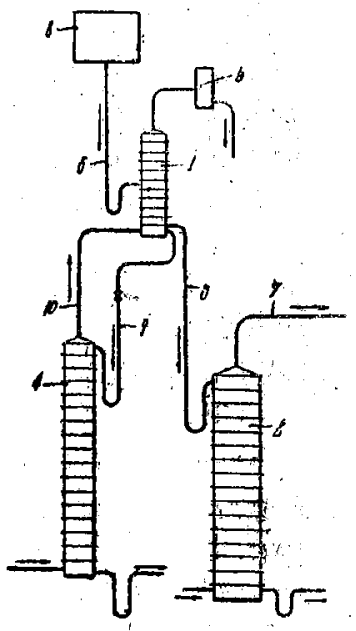
厄 100lの酒精を粗溜塔 2 から溜出されるには $157 \mathrm{~kg}$ の水蒸氣 を要し，粗溜裝置全體では $214 \mathrm{~kg}$ となり前者の約 $84 \%$ 水 蒸氣所要量でよいわけで岕る。其の他粗溜塔 2 の断面樻を摍少 することが出來る。（田邊武夫）

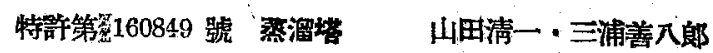

本發明は塔胴 1 の內壁に角狀支片 8,8 を對峙して固定し其 の上Kアングル片 6,6 を水平に固 定し，下方棚 2 の通策 


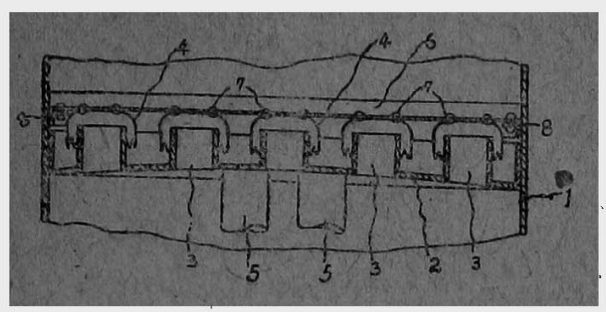

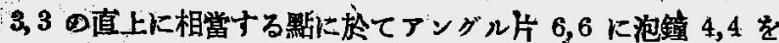
定着しその下部を棚 2 の上の液屏內に浸瀆寸る如くしたもの である。本登明は泡鐘か淔接棚板又は通氣管飞依り支持されて るない、瓷に棚板に重さのかかることを防ぎ且棚板が䇥曲してる ても蒸留效率に影慗することがない。(田邉武夫)

特許第 161219 號 フルフロール覆裂法

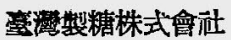

本發明は水及醌酸メチルアルコール等の不純物を含有する粗 製フルフロールにベンゾールを添加して藎溜し，水及不純物を ベンゾールの共沸混合物としてて溜出せしめ蒸溜牫渣としてフ ルフロールを殘留せしめる

けのであつて, 精溜荅 1 は 部庆間接加熱蛇管 6 , 上 方に命却器 7, 分離器 8 を 備へて居り，粗製フルフロ 一ルは管6 加ら塔 1 に供給 される。管 10, 11 からへ ンデールは添加され荅の上 部は $69 \sim 71^{\circ} \mathrm{C} に$, 中部は $85 \sim 90^{\circ} \mathrm{C}$ K保持され, 溜出 管 9 から溜出寸る共沸混合 物莱氣は冷却器 7 で㠜樎を れ分䧹器 8 で分別されべン ソ゚ールは塔に還流され不純 物は管 13 から抽出される。

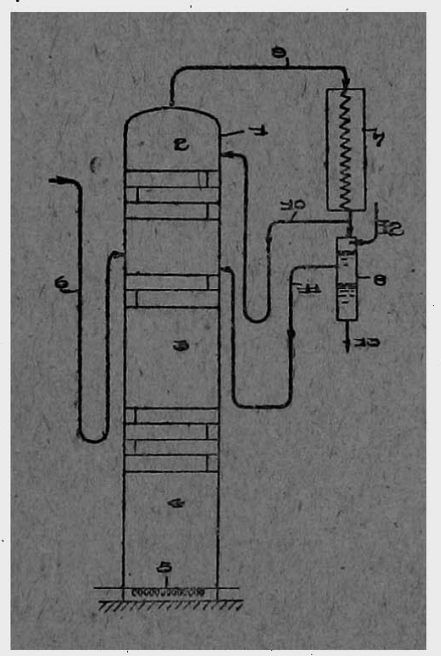

斯くてフルフロール忖塔に残留されれる。(田邊武夫）

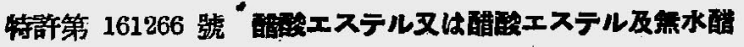

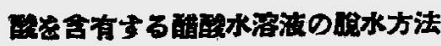

$$
\text { レ・ジニジーロ・ド・メル }
$$

本登明は醋酸エステル邓は醋酸エステル正無水醮酸を含有す

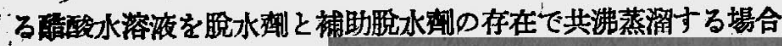

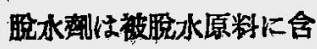
まれる酷酸ニステルに全 く满賞するすのとし補助

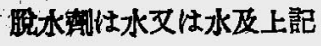
の睈酸エステルと共沸混 合物を形成才当物賀 (例 ※ば揮登油)を使用し， 而かすこす共潞湜合物け 上記の酷酸エステル㞋水 の共沸混合物の沸點々b

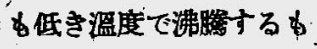
の、とし搭操作中醋酸エス

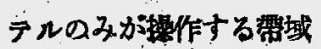

から被脫水原粦に依つて塔冈に持ち込まれる量け゚けの醌酸エス テル量を抽出するもので, 凝縮器 $\mathrm{B}$, 倾潟器 $\mathrm{C}$ を具へ, 醋㲔エ

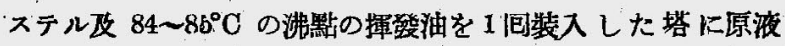
(醋酸 $10 \%$, 酷酸エチル $82 \%$, 水 $8 \%$ )を管1で章入する時 は, 塔 4 內に 2 個の帶域 $a, b$, 郎ち, 酷酸エチルが操倠する 帶域 a と揮發油が操作する帶域 b が形成される。水は傾湶槽 C で傾瀉で分別し管 3 から排除され, 補助脫水劑 (揮登油)は 管 4 で還流し帶域 a の中部加らは管 6, 弇 $6^{\prime}$ を經て荅 A 內

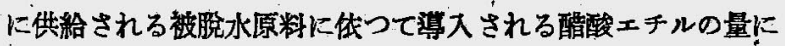
相管する量の醁酸エチル液が排出される。この液は冷却器Hで 冷却され再び醌酸抽出用に使用される。(田邊武夫)

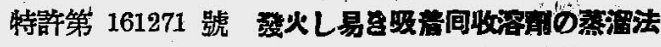

三浦 賁 -

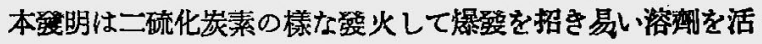

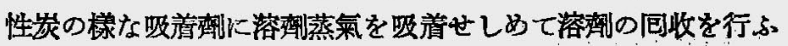
に當つて, 溶劑の吸着後吸着器內の空茶を水で全、置換した後 蒸溜用水蒸氣を以て水を 排除し引櫝き水蒸氣蒸溜 處理を行ふ方法である。 例へば活柽 $10,11,12$, 13 を閉ち活烃 11を開い て管より二硫化鈥素含有 蒸氣を䢪入して溶狱を活 栍炭素層 2 に吸着せしめ 摩ズがを管 4 より排除す る。活性炭の吸着度が飽 和度に近ついた場合柽14 を閉ち栓 10,11 を開い て管5より水を入れ樶着 器 1 內に克滿した水が管 6 の活柽 $11^{*}$ より上に昇

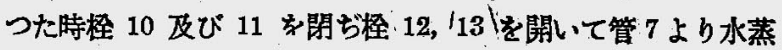
氣を医揆すると裝置 1 內の水は凝縮器 9 に逨る導管 8 を經 て管 15 より排出され，水の排出後は活珄炭に吸着の溶劑恃管 7 より流通する水蒸氣に脫着して疑樎器 9 に涼かれて水蒸氣と 共に凝縮し管 15 を通じて回收される。（田傻義一）

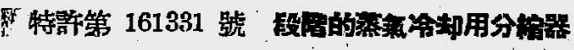

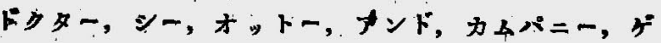

$$
\begin{aligned}
& \text { ゼルシ+フト, ミ,ト,ベシュレンタテル,ハフシング }
\end{aligned}
$$

本登明は例へばヘンンジール 蒸溜に際し特にヘンンゾールの 純粹生成品を彆造せんとすする 場合, 復流命却器として蒸溜 物冷却器の前位に校され る段階的蒸氣冷却用分縮器 に於て凝結物流出導管闪飞殹 止噴嘴を內設した點を特徽と してるる。從來各個の分縮器 段階間には圈力差が存在する 烏凝結物流出に對与る浸清閉 塞部を必要としたが，流出管 をサイフォン管とせば裝置は

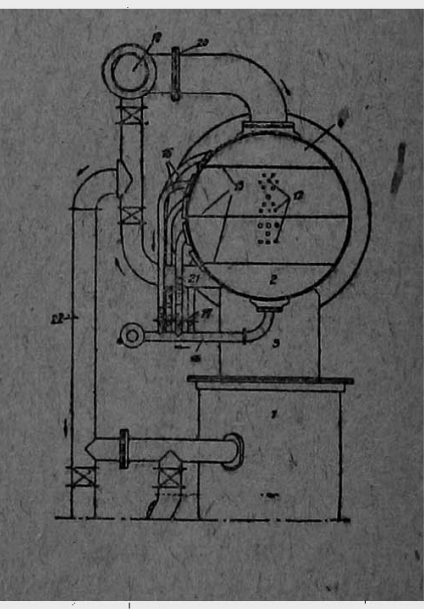


渚しく監悓し難いものとなり堂溜の終了後サイフォン管の內容 物を流出せしめることは出來ない。然るに本發明では各段階か ら流出管 15 に按止貲踭 17 を內設した雼に上記の御點なく而 加蒸氣の流通は充分に阻止出來る。(田邊武夫)

特許第 160628 號 フルフラル繁渭方法

\section{株式會话生物工學研究所}

\section{8. 吸收・吸着・抽出}

、特許第 160897 號 連續式抽油裝置 豐年製油株式會往 本登明怯螺旋形輸运裝置 $\mathrm{T}$ 及加熱外套 $\mathrm{R}$ を備へた水平圆 "筒型抽出權を一本以上備へ，その最後の抽出權の末端に管Dを

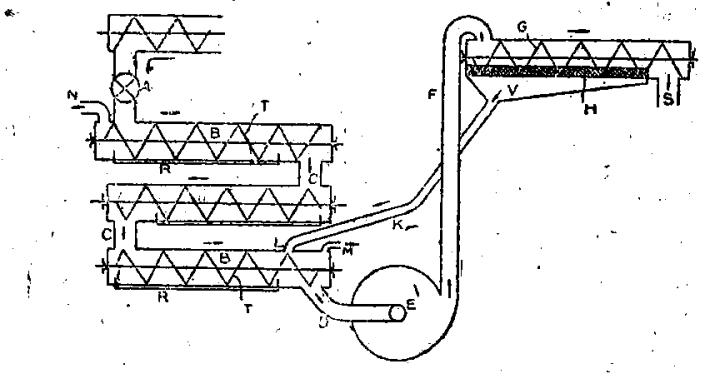

設け之を瀜卷唧筒 $\mathbf{E}$ の吸入側に連通せしめると共に吐出側は 之を管 F を介して濾渦轉送裝置に連通せしめ, 新しい溶劑は

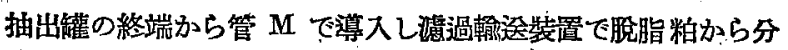
離された溶劑は管、で抽出罐の終端に近き部分に還流せしめ る如くしたものである。本唚明は抽出罐を水本式にした雼に螺 旋形輸送裝置充分作働し且裝置全體も高くなることなく操作 することが出來る。(田邊武夫)

特許第 160918 號 樹脂又は油脂類の溶甽による抽出法 犽田 次郎

此の發明は松根, 檜根の如き樹脂抽出原料又は大豆, 茶種の 如き製油原料を溶劑にて抽出する方法に關するものであつて,

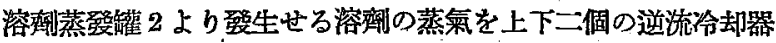
4",4' を管 5 にて連結せるbのの下方に導き下方の逆流冷却 器 $4^{\prime}$ に於て抽出飞適 當な溫度を有せしむる 粶に液化せしめ，殘餘 の未液化蒸氣恃上方の 逆流冷却器 4 " K於て 下方の冷却器 $4^{\prime}$ ‘る 与低罝度飞て液化包收 、 ᄂ, 之等の液化溶劑老 抽出鑵 1 中の被抽出物 の底部に導入せしめ, 份抽出䠰 1 中の溶液は 表面より逐次溶劑孛揮 登せしめて溶質を探取 する樣なしたのである。

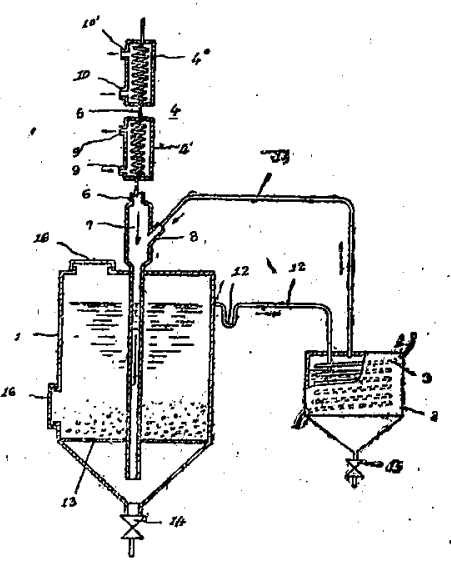
斯くて管 7 より供給さ

れた溶劑は抽出䌯 1 內を上昇し以て抽出罐 1 内の溶劑を絶へず 循䍙せしめつつ之を被處理盗料に接觸せしめ伡つて抽出操作を 容易となしたのである。(濢浦)

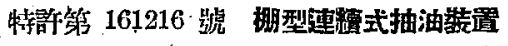

大日本飞ルロイト株式會社

10. 運 搬。眝 藏

特許第 160795 號 可器吐出往復唧简 ，服部 成一

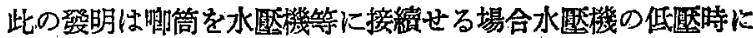

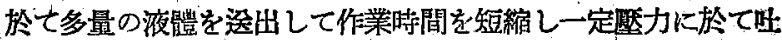

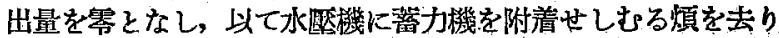

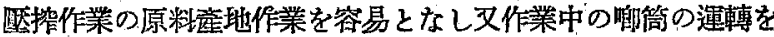

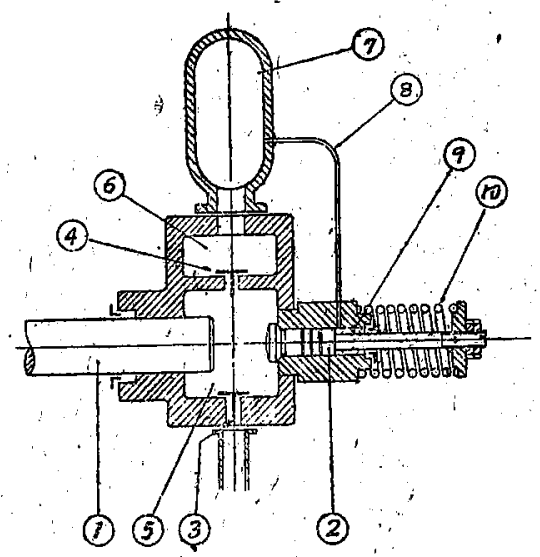

停止する事なく動力の消費を小となしたものであつて，主唧子

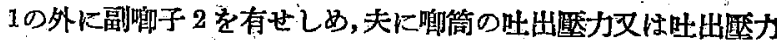

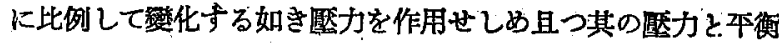
する樣に裁條 10 等の如きものを設けて副报子2 の押退量が吐 出筑力に正比例寸る樣になしたのでする。斯くの如くして吐出

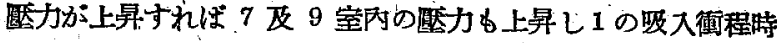

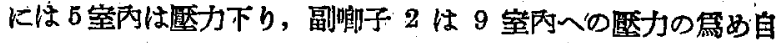

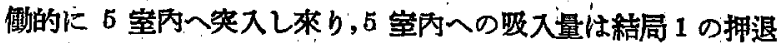
量より 2 の押退量を差引小大量となり，次で医縮衝程にては 2 は夫に從つて原位置に復獻するのでする。斯かる事を曲軸一间

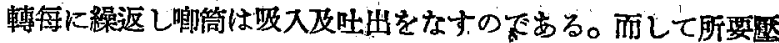
力にて 1 及 2 の押退量が同一となる樣なすには發條 10 を調整

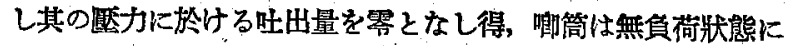
て運轉し得るのだる。(澤浦)

;特等第 161507 號 低溫派䭪容器 小野田 忠

本發明は液體酸素, 液體荎素, 液體空氣等低溫液咀の容器剆

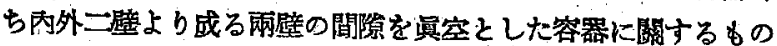
であつて, 從來此種の容器俚銅と二;ケルと互鍇とを使用して るたが，現今二,ろルの使用困難である第ニっケルを使用しな いでニっケルを使用した合金と同棌な效果を持たせたりので， 純銅 64〜68, 純亞鉛 36〜32 の制合を有する 具鍮板からなつ てるる材料を使用する低溫液體容器である。從來の低溫液體容 器の組成材の如く銅 50 , 亞釦 $30,=$, ルル20 の制合の合金

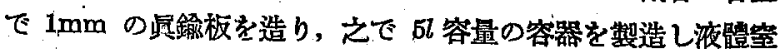
素の蒸登量(常溫に於ける)は 72 時間であつたが; 本硒明に依 る合金例一ば銅 66, 亞鉛,34の合金材で製造した答器で同樣の 試驗をした結果 152 時間であつた。（田邊義一）

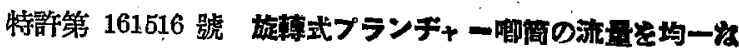

1 らしをる裝置 山本福一 - 林 重孝 
本登明怯本體 1 と包轉體 2 .とを同一軸心 3 上に在らしめ;

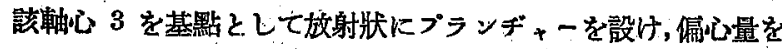
孌へず曲肘を用ひないプランヂ+一嘅筒に於て，數個のプラン ヂャーを其の位置の如何に拘らず常に各個㚬等な衝程運動を篇 さしめる䉆问轉體 2 の兩 側若くは片側に軸心 3 に 對し偏心的で而す监圆 とせず特殊曲線上り成る 環狀郎ちアルキメデス㧫 線狀のブランデャー衝程 運動案內瑇を設け，ピン 6,滑り金 7 等にようて兩 者 4,5 を關聯せしめた旋 轉式プランデャ一揤筒の 流量を均一ならしめる裝 置である。一般に繰出量 可變の䂵轉式犲根咧筒文 注曲时を安用ひたブランヂ

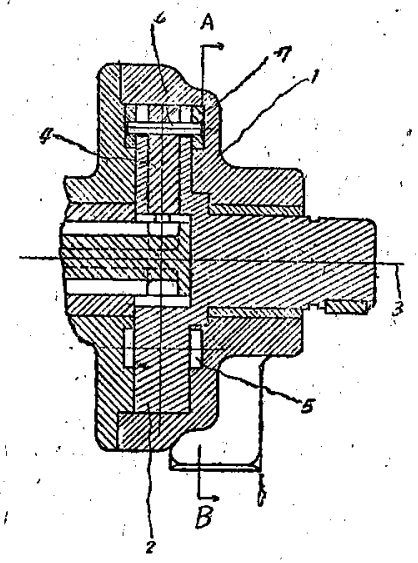
ャ一唧筒の繰出す液醴の流れは所謂水樋作用そなして圆滑で均 一な流れを得る事が殆んど不可能で他に幾多の利點方ちつても 使用しなふ心つたが，本管明置に传れば完全確葢に液體の流量 を均一にし，工作機械の往復運動，動力の傳達又は圆滑な四轉 運動を必要とする機栈の動力傳達其の他均一流を要求せられる むのに使用すれば高㻺と强力を備へるプランヂ、一卵筒又は原 動機としての長所老探用し得られる。(时邊義十)

特許第 160896 號 大豆抽油其他濯出裝㯰に於ける粕排出處 理装雚の改长 豐年製油株式會社

\section{1. 材料。防 蝕}

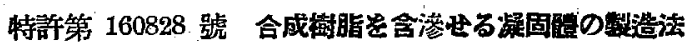
昭和耐火工株式會社

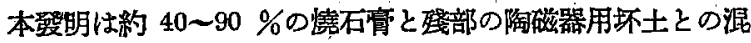
合物に水を加へて流動性を與人普通の石㜔篮造法と同樣にして 所要の形を成形して乾燥し; 此の塑造物を渐次溫度を上け゚なが

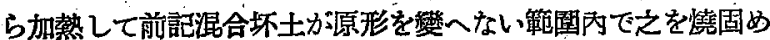
て基體を作り，合成樹脂の初期縮合物を約 $60^{\circ} \mathrm{C}$ に加蓺したも のに前記基體を約 $100^{\circ} \mathrm{C}$ 以上の溫度となして浸漬せしめて前 記初期縮合物を淁入せしめ，此の處理物を大氣厴又は夫れ以上

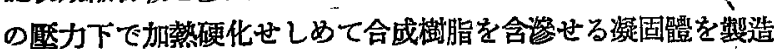
すろ方法である。乾㶹した塑造體の燒成溫度は700〜 $1,200^{\circ} \mathrm{C}$, 最後の浸漬物の處理溫度は的 $60 \sim 150^{\circ} \mathrm{C}$ 迄泟炊上昇せしめ る。(田鬽新一)

\section{2. 測定・調 郎}

特許第 161469 號 液量表示裝置

富士航空訫器秼式會良

多雚の液槽の液量を表示するには夫々放槽に表示器を其へる 必要があるが多大の占有場所を必要とする鳥に航堂楼等では不

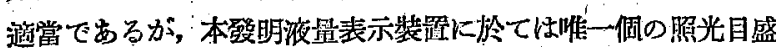
板を使用し其の指針を各液槽の何れかの液位應動装置 5 との連 絡に應じて運動し，表示板面を此の連絡動作に關聯して連絡せ る液槽の液面限界籍徫に相應した範圍を照光せしむる樴にして

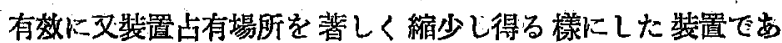
る。例へば航空機油槽設備に就て說明すれば,油楷 1，2，3．何 れか例一ば油槽 1 の油量を測定する場合栓 6 を開放すると之に

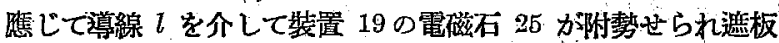
22 怯第 2 圆の如き位置に押出され，第 1 墖の如く照光面 16 か 現出せられる。又他方に於て油位應䡃裝置 5 の油位に應じセル

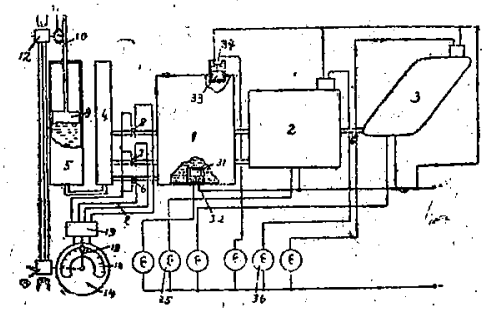

第 1 圆

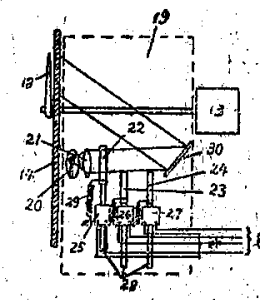

第 2 骨
シン電機 13 Kよ り指針 18 が包動 せられる䉆油槽 1 の油位中心を基點 として油槽 1 の油 量が容易に指示せ られる。油槽 2,

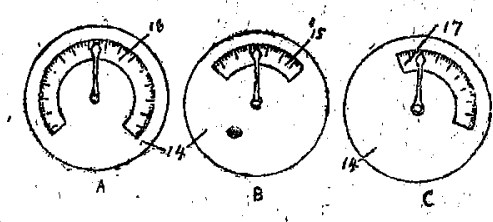

第 3 圆
3 の油量も同樣に表示せられる。更に各油槽の最大油量, 最小 油量を總て同時に表示せられる装置を附加するととが出來る。 油位應動裝置 つ中には浮子 9 と共に异降与る齿桿 10 があり，

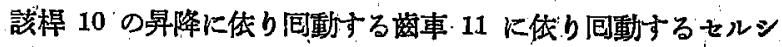
ン電機 13 は他の電機 13 之接續され, 14 は臊光装置19Kよ り表示される 照明表示板, 18 :電機 13 て四動せられる指針 で, 14，15，18,19 は一個の表示器とにて構成せられる。裝置 19 は栓 6,7,8 の何れかの閉放に關聯して開放した烃の所厥す

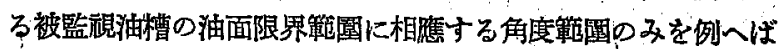

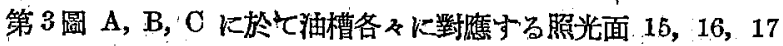
に示才如く炤光されるのである。(田邊義一)

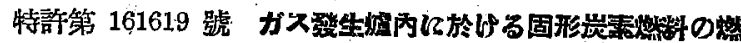
燒を測定する㢣置

$$
\text { トヨダ自動車工業株式會证 }
$$

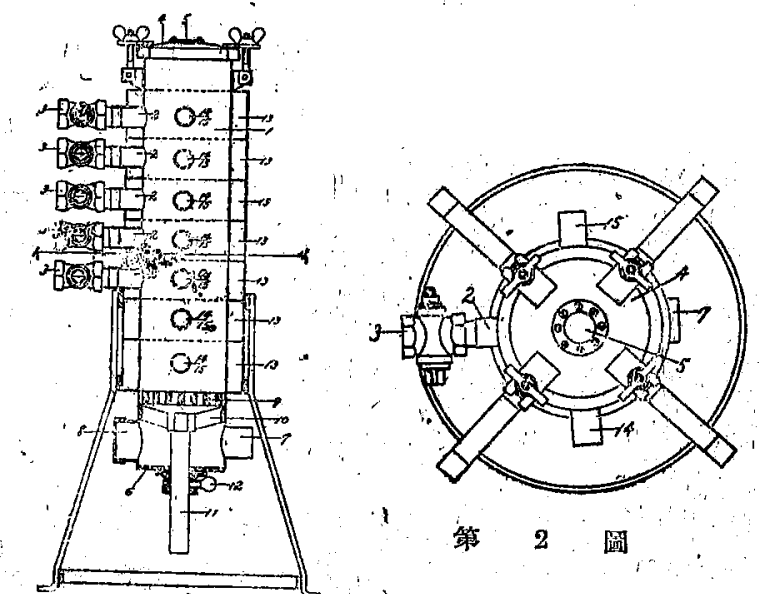

第 1 圆 
此の發明は一般ガス登生爐に比較して著しく直徑小なる踶筒 型の發生榩 1 の上部片側に互に等距離の間隔にある数简の發生

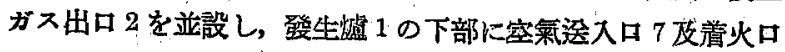
8 を設け, 發生爐內部に界降の調整可能なる火格子9を設け,

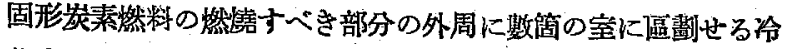
却水套 13 を設け, 斯く

乙て發生爈內に於て固形

炭素燃料を燃爟せしめす

つ前記がス出口 2 を各筒

认開き且つ火格子 9 の位.

置を崉降して火格子 9 の

上面とガス出口 2 の中心

との距離を適宜に定め;

而してガス出口 2 より噴

出する燃料ガスの性質を

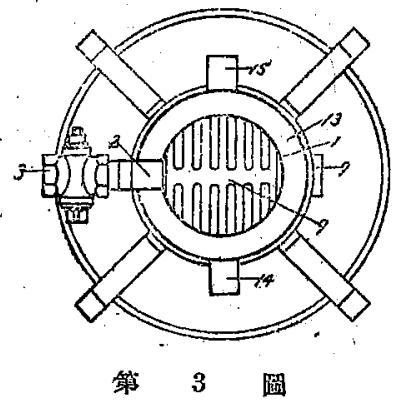

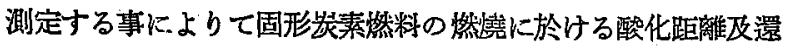

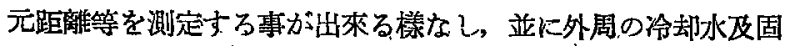

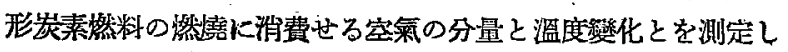

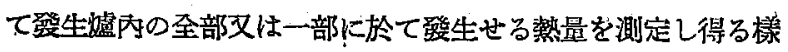

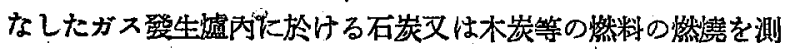
定する裝置である。(翌浦)

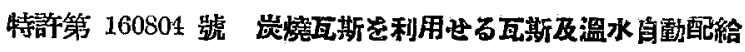
裝䈯 近松 端浩

\section{3. 高壓・回收・反應}

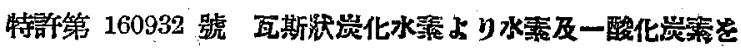
造する方法 住友化學工業株式會证

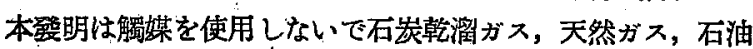
分解ガス等のガス爿炭化水素又はガス狀炭化水素を多量に含む ガスに酸素又は酸素に富む室氣を添加してガスの部分燃等を行

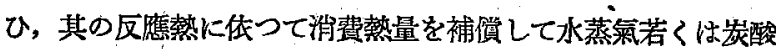
ガスにより炭化水素を熱分解せし むるに當つて，分解裝置付を通過 するガス流の方向を週期的に交番 せしもると共に分解生成ガスの一 部分を常に循環して處理ガスの水 素ーメタン比を 4 以上に保持して 水素及一酸化炭素を制造方る方法 であつて, 原料ガスの稀䆁と水素一 メタン比の增加を計り煤煙の生成 之分解裝置內温度の局部的上昗を 防止したすのである。原䊅ガスは

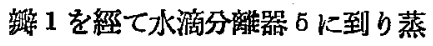
氣辫 3 上,りの水蒸氣及分解ガ不辨 2 上りの分解生成ガスと湿合し部 6 を經て內側警熱空 7 を上流しな がら䃥熱され，大部分の炭化水素 は分解乙燃签室 8 亿達し辩 4 を經

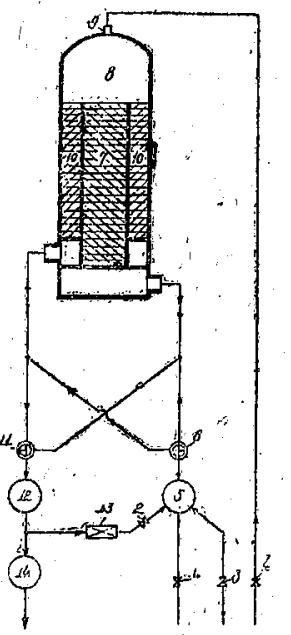

て酸菜噴出口 9 よりの酸素で部分燃焳を起し $1,500^{\circ} \mathrm{O}$ の高温

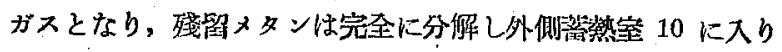
“保熱體を加熱しながら自らは冷却して瓣 11 を經て一次冷却器 12 飞到り更に冷却されて最終冷却器 14 を經て收得せられ, 一

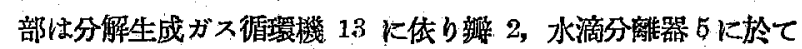
原料ガスと混ずる。分解操作續行で堂 7 内の溫度は次第水降下 乙空 10 內の温度性昇り操作为困難になる適當の時期にガス流

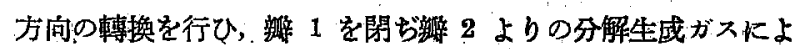
り室 7 内に溜る多量の未反應炭化水素含有ガスを完全に置換し

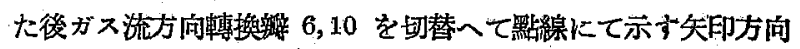
にガスを尊入するのである。(田邀義一)

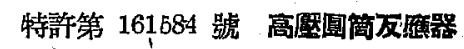
坂本，猛

本發明は高座工業例へば石炭液化工業或はアムモニフ合成工 業等に於て使用せられる高国容器に關するものであつて, 所定

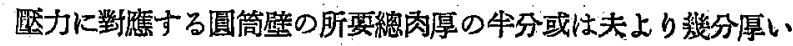

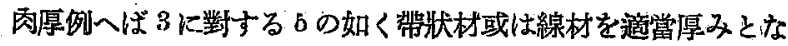

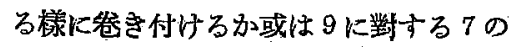
如く薄板を一枚每に卷きう计緊緢し端部 を熔接して之を次々に外部に施して多層

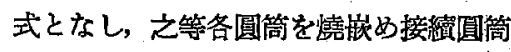

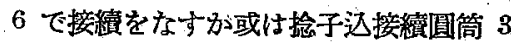
で行ふかして外筒となすかヌは內部泪筒 が二個以上の場合は夫等の端部接縝部分 を外方に向け喵がり勾配となる樣に圆錐 形となし，圆筒接着部分に其の內面に圆

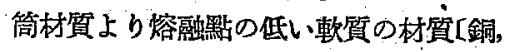

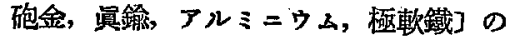
パッキング4を施したりのに, 本容器篮と して一個或性二個以上の環狀物 11,13

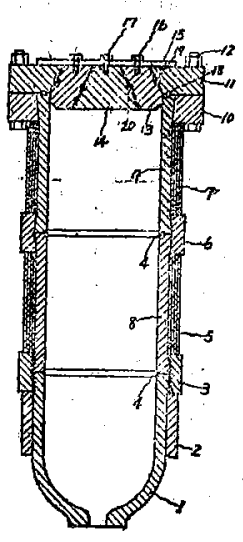
を嵌め込み更に圓艋狀物 14 を嵌め迈久 接着は小俓物总總て容器內部に相當する方向上り容易に行ひ处 部上り拔き出し出來略勾配を有する圆錐形々なし各接着部分に パッキング 19, 20 を裝㣁したすのを組合せて構成したすので ある。(四邊義一)

特許第. 161585 號 石油合成怔置 坂本。猛

本發明は除熱媒體として溫水を使用し約 $200^{\circ} \mathrm{C}$ 以下の比較 的低き反阼温度を保持与る如くした公知の $\mathrm{CO}-\mathrm{H}_{2}$ 系石油合成

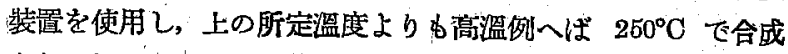
を行ふ場合, この所定温度火於ける水蒸氣㗨よりも高くない蒸

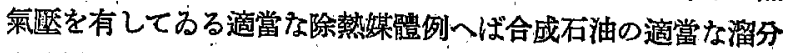

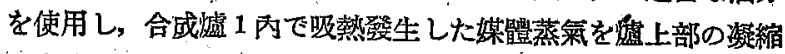

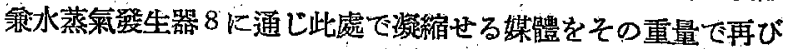
合成烳 1 に流入せしぬる如くした めのて，從來は合成爈 1 て發生し た蒸氣住管 6 , 蒸汽ドラA2, 管 7 で外部に導出し所要目的认值用さ れ, 補粭水任管 3 名蒸汽ドラム 2 にスり合成反怔溫度に保持され 管5を經て合成迶 1 に入るが，本 發明怯合成爈 1 加發生する油蒸

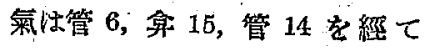
乑缩器 8 に到り 此處で㠜缩した

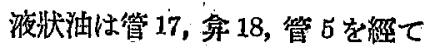
合成嘘 1 K入り, 此の經路では蒸 汽ドラムム 2 は全然無關俰とする。 一方水柔統で恃給水管 3 蛙汽ト

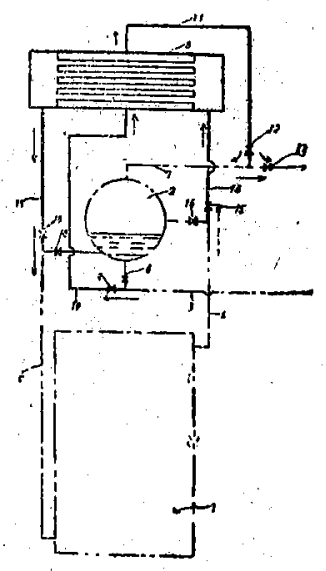


ラム2 に薄結することなく管 10 を經て㠜縮器 8 に入り油蒸氣 の潜熱を吸收して水蒸氣となり外部の所要目的に使用するので

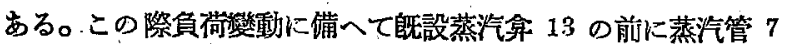
と新設蒸汽管 11 ．とを連結しその間に弇 12 を設ける必要があ る。(田邉武夫)

特許第 160638 號 栄化水茨の分解法

15. 雜

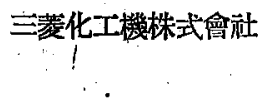

\section{特許第 160742 號 水電解橧，昭和電工株式會社}

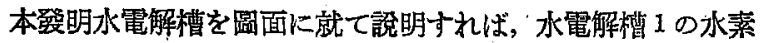
導出管 2，酸素導出管 3 をガス野槽にガス排出管 8,9 で連通 されてるるガス洗深堂 4,5 水面下に開口せしめ，ガ ス 沙深室 4,5 の洗临水 6,7 を洗䧾水連通管 $13 ; 14$ で湩通せしめた装置 に於て，上方が一方のがス 洗滌室 \pm のガス部分とガス 連通管 16 で連通せる餘水 溜室 15 を設け, 餘水排出 管 18 を該空內適當の高さ に開口せしめ,一端は餘水 溜室 15 の底部に連通し他 端は他力のガズ洗條音 5 內 に於て餘水排出管 18 之略 同一高さの部分に於て開 口する餘水連通管 17 を設 けた水電解槽である。例へ

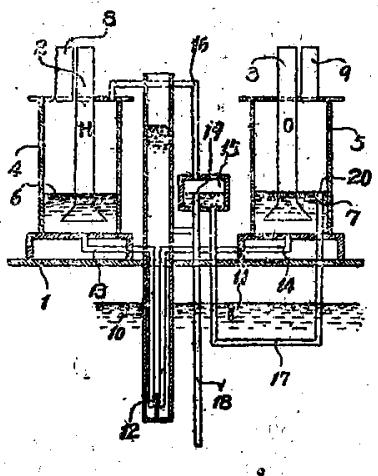
ば水素側ガス貯槽のガス籃が增した場合，洗涤室 4 の液面は

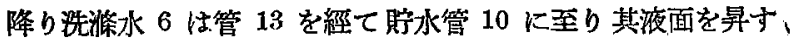

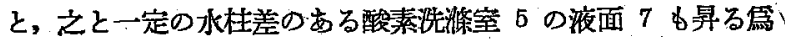

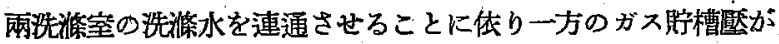

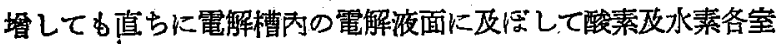
の電解液面に差を生ぜしもることがない。ガス洗源で增加した 洗㹣水の過剩部分性餘水排出管 18 より出排される。餘水溜室 15 の水面は洗策空 4 の水面 6 と同一高さに保たれ水素ガス

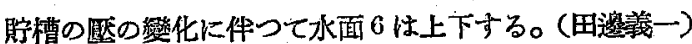

特新第 160931 社 フルフラル笠造法

株式會社生物工學研究所

本發明は分解と蒸溜とを同時に行ひ熱量を節約すると舆に演 度高きフルフラルを收率良く 容易炕得んとするすのて，多 數の棚を有し各棚に蒸氣が上 梨し得る如くしたキャ,プ又 は紐孔を有し同時に溶液が下 降し得る邆流管を有し加㿄加 熱に㨽へる裝置を使用する。 ので, 酸性文は中性デントー ズ溶液を原液槽】から管 1 で フルフラル分解蒸溜裝置 IJ

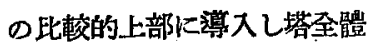
を加㗨加熱する。其の緊力は $2.0 \mathrm{~kg}$ ，溫度は $120 \sim 170^{\circ} \mathrm{C}$ 厄

ある。フルフラル分解蒸溜裝置 II の原液供給個所より上部郎

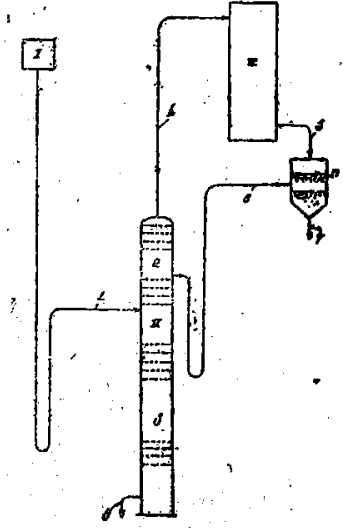

ち，2 の部分はフルフラル㟟縮荅で，下部郎ち 3 はベントーズ のフルフラル分解瓜焀フルフラル塔の役割をなすのである。剆 ち 2 の部分を加壓蒸溜に附し 2 の頂部から管 4 を通じてフ ルフラル水の共沸混合物を溜出し, 凝縮器 III で凝縮し管，5 を通し分離器 IV で 2 層に分別し，上層は管 6 で還流し、下層

- 、は管 7 から採取し純度 $95 \%$ の工業用フルフラルを收得する ものである。斯くの如く本登明は分解と蒸溜とを同時にし熱の 篩約をなした琶化特徽がある。(田邀武夫)

特許第 161330 號 反流式段媘的洗潗器

$$
\begin{aligned}
& \text { ドタター・シー・オットー・アンド・カムバニーゲゼルシ } \\
& \text { ヤト・ミトペシュレンクテルハフッング }
\end{aligned}
$$

本發明は水又は酸に依りアムモニアガスを所謂洗沙泊に徒つ て炭化水素化合物を，水又はアルカり溶液に化り炭酸ガスを， 或はアルカり溶液に传り硫化水素を洗滌与る反流式段階的洗源 器に關するものである。同一高さに配置せられた洗浣塔 $1 ， 2$, 3，4 は入口 15 上り第一塔 1 に流入する原料ガスが各塔の內

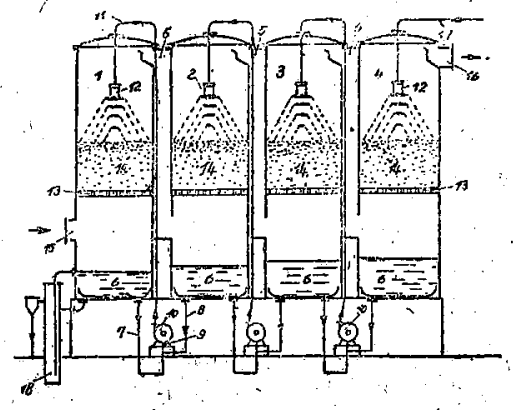

部に於ては下方よら 上方に向ひ流れるが連結導路 5 內に於ては 逆に流れる樣に導路 5 で互に連結せられ，ガスは清汾狀態で塔 4 の出口 16 より出る。洗源液體はガスと反對に塔郎ち洗涤段 階を上方より下方に流れて集收底 6 內に集る。塔 1 及 2 は酎 路 7 及 8 に依り連通し唧筒に連結せられる。唧筒 10 は㟷 1 及 2 の底より抽出する液體を埒路 11 を介して荅 1 の撒布器 12 に供給し, 撒布器 12 は洗涤液體を格子 13 上の充異層 14 上に撒布する。集收底より來る洗源夜體は唧筒 10 ，望路 7,9 , 11 を通り循環するが; 過剩の液體は塔 2 より等路 8，9，11 を 通して塔 1 に供給るれる。唧筒 10 で塔 2 のより過剩の液體

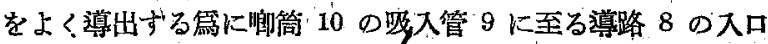

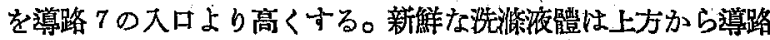
17 を通つて塔 4 に供給几，各個の唧简 10 に依り塔 3, 2,

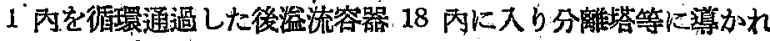
る。（田邊義一） 